\title{
Micronutrients and Soil Microorganisms in the Suppression of Potato Common Scab
}

\author{
Jan Kopecky ${ }^{1}$, Daria Rapoport ${ }^{1,2}$, Ensyeh Sarikhani ${ }^{3}$, Adam Stovicek ${ }^{3}$, Tereza Patrmanova ${ }^{1}$ and \\ Marketa Sagova-Mareckova ${ }^{3, *}$
}

1 Epidemiology and Ecology of Microorganisms, Crop Research Institute, 16106 Prague, Czech Republic; jkopecky@vurv.cz (J.K.); dariarapoport@gmail.com (D.R.); patrmanova@vurv.cz (T.P.)

2 Department of Genetics and Microbiology, Charles University, 12800 Prague, Czech Republic

3 Department of Microbiology, Nutrition and Dietetics, Faculty of Agrobiology, Food and Natural Resources, Czech University of Life Sciences, 16500 Prague, Czech Republic; ensyeh114@yahoo.com (E.S.); stovicek@af.czu.cz (A.S.)

* Correspondence: mareckova@af.czu.cz

Citation: Kopecky, J.; Rapoport, D.; Sarikhani, E.; Stovicek, A.;

Patrmanova, T.; Sagova-Mareckova, M. Micronutrients and Soil Microorganisms in the Suppression of Potato Common Scab. Agronomy 2021 11, 383. https://doi.org/10.3390/ agronomy11020383

Academic Editor: Juan Jose Rios

Received: 8 January 2021

Accepted: 17 February 2021

Published: 20 February 2021

Publisher's Note: MDPI stays neutral with regard to jurisdictional claims in published maps and institutional affiliations.

Copyright: (c) 2021 by the authors. Licensee MDPI, Basel, Switzerland. This article is an open access article distributed under the terms and conditions of the Creative Commons Attribution (CC BY) license (https:// creativecommons.org/licenses/by/ $4.0 /)$.

\begin{abstract}
Nature-friendly approaches for crop protection are sought after in the effort to reduce the use of agrochemicals. However, the transfer of scientific findings to agriculture practice is relatively slow because research results are sometimes contradictory or do not clearly lead to applicable approaches. Common scab of potatoes is a disease affecting potatoes worldwide, for which no definite treatment is available. That is due to many complex interactions affecting its incidence and severity. The review aims to determine options for the control of the disease using additions of micronutrients and modification of microbial communities. We propose three approaches for the improvement by (1) supplying soils with limiting nutrients, (2) supporting microbial communities with high mineral solubilization capabilities or (3) applying communities antagonistic to the pathogen. The procedures for the disease control may include fertilization with micronutrients and appropriate organic matter or inoculation with beneficial strains selected according to local environmental conditions. Further research is proposed to use metagenomics/metabolomics to identify key soilplant-microbe interactions in comparisons of disease-suppressive and -conducive soils.
\end{abstract}

Keywords: micronutrients; mineral solubilization; inoculation; suppressive soils; antagonistic strains

\section{Introduction}

At present, both agriculture science and management seek to understand ecological processes which are relevant to the control of plant diseases [1,2]. New findings are expected to diminish the use of agrochemicals, which decrease the biodiversity of non-target organisms, including microbial communities in agroecosystems [3]. Proposed approaches focus on biological protection, mostly using microorganisms supporting plant growth and health [4]. However, more traditional approaches can also be used. One of the well-studied mechanisms of plant protection concerns providing plants with sufficient resources/nutrients such as nitrogen, phosphorus or potassium but also trace elements [5]. Many agricultural soils are deficient in one or more nutrients, and the production of crops depletes, particularly, micronutrients, because macronutrients are typically supplied in high amounts [6]. That leads not only to suboptimal plant growth but also to decreased plant immunity, which is influenced by their metabolic status $[7,8]$. Thus, composed plant nutrition is critical for disease control. That is because a delicate balance between the specific nutrient requirements of various potato cultivars and the soil chemical conditions need to be established [9-14].

Common scab (CS) is a disease potentially affected by plant mineral nutrients [15]. Previous studies associated nitrogen, phosphorus, potassium, calcium, magnesium, iron, zinc, manganese, copper and aluminum with CS severity or incidence by their content 
either in soil or plant tissue [15-17]. The use of nutrients to control CS was investigated but the effects differed by location, cultivar and year [16-21].

The second studied mechanism of disease control involves plant-microbe-soil interactions, which include (1) antibiosis; (2) competition with pathogens, (3) induction of systemic defense response, (4) plant growth promotion and also (5) increased availability of nutrients, which all affect plant defense [22]. It was suggested that, particularly, the soil [23] and potato plant microbiomes $[24,25]$ are important in controlling plant diseases.

Common scab of potatoes (CS) is a disease caused by pathogenic Streptomyces spp., which are distributed worldwide and, thus, adapted to various soil conditions [26]. In the past, the disease was treated by several pesticides, e.g., formaldehyde, urea formaldehyde, manganese sulphate, pentachloronitrobenzene and chloropicrin, whose use is now limited. In spite of increased research efforts, no treatments provide a reliable control of the disease across locations [26].

Most of the generally known microbial activities connected to plant disease control were also observed in CS-related interactions, particularly in suppressive soils [27-30]. Extensive research was conducted with supplementation of antagonistic strains to soil or improvement of the whole microbial communities using organic substrates reviewed in [31]. Above that, many cases of pathogen suppression by the microbial community were also related to the soil nutrient status [32,33]. Yet, no conclusive results useful for disease management were determined.

Consequently, in this review, we combine the chemical, physiological and microbiological research concerning CS to uncover the underlying processes which could be used for disease control. We focus on the effects of micronutrients because their sufficient amount is required for many physiological processes which support the defense against plant diseases. Additionally, micronutrient availability is relatively easy to manage [6]. We also recognize that microorganisms are integral components of soils, and therefore, their participation in potato plant nutrition and protection against CS needs to be considered in disease control. Finally, we recommend approaches for the most appropriate management strategies.

\section{Individual Nutrients Affect CS Severity}

Potatoes require optimal levels of essential nutrients throughout the growing season. Therefore, disease severity may be influenced by nutrient limitation, particularly at periods of fast growth [34]. Potato plants respond to the presence of the CS pathogen and nutrient conditions by accumulating various macro- and microelements. A significant correlation was shown between the degree of infestation by CS and the contents of $\mathrm{Ca}, \mathrm{Mn}, \mathrm{K}, \mathrm{P}, \mathrm{Fe}$ and $\mathrm{Mg}[15-17,35]$ in potato periderm or other parts of plants. The ability to accumulate different macro- and microelements also differs between cultivars and is further associated with resistance to CS [36]. However, it seems that the accumulation of different nutrients in potato periderm results from various processes, and thus, only some interactions are indicative of CS effects or can be used for its suppression.

\subsection{Micronutrients}

\subsubsection{Calcium (Ca)}

Ca relationships to CS are some of the most studied, in combination with soil $\mathrm{pH}$. High total calcium levels in soil and also composed exchangeable $\mathrm{Ca}$ are often positively correlated with CS severity $[17,27,28,37]$. However, addition of Ca and $\mathrm{K}$ to acidic and neutral soils increased CS severity only in the neutral soil, showing that $\mathrm{pH}$ and $\mathrm{Ca}: \mathrm{K}$ ratio are more important than the content of $\mathrm{Ca}$ in soil alone [38]. Similarly, the irregular relationship between soil $\mathrm{pH}$, exchangeable Ca and CS development (e.g., [35]) was explained by interactions with other nutrients, including phosphorus, nitrogen and manganese $[17,39]$ (Table 1).

Limitation of plant growth is relatively unlikely with Ca because it is a component of several primary and secondary minerals and is commonly present in ionic form (positively charged $\mathrm{Ca}^{2+}$ ), which is considered biologically available. Limitations may occur when 
it is adsorbed on soil colloidal complexes or due to human-induced acidification of soils, when Ca deficiency is caused by antagonistic plant uptake of metals such as aluminum, potassium and manganese [5,40].

However, limited Ca uptake influences the disease development because in plants, $\mathrm{Ca}$ affects the stability and function of membranes and cell wall structures $[5,40,41]$. Furthermore, Ca serves as a second messenger triggered by different environmental stimuli, including pathogens, so it is needed for plant defense [40]. In CS lesions, the Ca level is elevated [42] and it is even higher in dry soil conditions [43]. Thus, the high Ca level in the tuber periderm of diseased plants [36] shows an effect of infection rather than a cause [35]. However in healthy potatoes, a positive correlation between the Ca content and CS severity suggested that susceptible cultivars accumulate higher amounts of Ca [44].

Consequently, the total $\mathrm{Ca}$ content in the soil does not seem to be a good predictor of CS disease because it interacts with many other soil nutrients, $\mathrm{pH}$ and soil moisture and is affected by potato plant genetics. However, occasional liming of low-pH soils is recommended for prevention of $\mathrm{Ca}$ limitation, which also leads to increased disease severity. Above that, manipulation of soil $\mathrm{Ca}$ leads to fluctuations in soil $\mathrm{pH}$, which may further improve CS prevention because different pathogenic streptomycetes are adapted to specific soil $\mathrm{pH}$ levels, and thus, its decrease or increase may suppress their populations [15,45]. In contrast, the selection of cultivars which accumulate lower amounts of $\mathrm{Ca}$ in the periderm may be a good strategy for CS control (Table 1).

\subsubsection{Sulphur (S)}

The application of elemental sulfur, calcium sulfate and ammonium sulfate reduced CS infection and severity [46,47], and above that, sulfate fertilizers enhanced biodiversity and antibiosis [46,48]. CS severity was also negatively correlated with soil S content [32]. Yet the effect of elemental sulfur and ammonium sulfate on the reduction in CS was not consistent [47].

Sulfur availability in soil depends highly on soil bacteria because more than $95 \%$ of total sulfur is bound to organic molecules in the form of sulfate esters or carbon-bonded sulfur (sulfonates or amino acid sulfur). Bacteria participate in both the formation of those compounds (sulfur immobilization) and sulfur release in the form of sulfate, which is available to plants [49]. Additionally, different microbial communities are involved in the consumption of various sulfur sources and supplying of sulfur to potato plants [50].

In the plant, organically bound sulfur in the form of various sulfur-containing metabolites is involved in cellular self-defense processes including detoxification of reactive oxygen species and other redox reactions, collectively termed sulfur-induced resistance or sulfur-enhanced defense [51]. Additionally, sulfur deficiency also has an indirect effect on plants as it reduces uptake of other elements such as P and K [40,52]. To improve CS control, it seems that the increase in decomposition processes by priming with additions of new organic matter may lead to the release of $S$ from older soil organic matter and support microorganisms increasing $S$ availability.

\subsubsection{Magnesium $(\mathrm{Mg})$}

In several studies, CS decreased and no pathogen (Streptomyces scabiei) was detected on potatoes grown in soils with high composed exchangeable cations including Mg [37]. Similarly, CS-suppressive soils were enriched in total Mg compared to CS-conducive soils [27]. A connection of $\mathrm{Mg}$ and CS suppression was also found in a resistant potato cultivar that also had a higher $\mathrm{Mg}$ content in the periderm compared to a susceptible cultivar [28]. However, in another study, the number of thaxtomin gene copies $(t x t B)$ representing the quantity of the pathogens in potato periderm was found positively correlated to periderm Mg content [32].

$\mathrm{Mg}$ availability in soil depends on soil weathering, moisture, $\mathrm{pH}$ and root-microbial activity, which are key factors determining the plant-available $\mathrm{Mg}$ pool [53]. Yet $\mathrm{Mg}$ is usually not limiting because it is present in various types of silicates and is relatively mobile 
compared to other cations such as $\mathrm{K}, \mathrm{Ca}$ and $\mathrm{NH}_{4}{ }^{+}$[54]. However, similar to other cations, deficiency of $\mathrm{Mg}^{2+}$ in the plant may be induced not only by its low soil content but also by other cations that compete with $\mathrm{Mg}^{2+}$ for binding to negatively charged clay particles or root apoplasm [55].

Magnesium is an important co-factor of more than 300 enzymes [53], including RuBisCO, a central part of a chlorophyll molecule [40], and also functions as a carrier of phosphorus in plants. Nevertheless, excess $\mathrm{Mg}^{2+}$ may also inhibit photosynthesis, particularly during dehydration [56] (Table 1).

Thus, for improvement of Mg-related limitation of plant growth and health, mostly a selection of cultivars with better Mg utilization may be recommended [44] or, in case of larger limitation, soil can be supplemented with dolomite, the most common $\mathrm{Mg}$ fertilizer.

\subsubsection{Manganese (Mn)}

High Mn content (Mehlich 3-extractable) was strongly correlated with low CS disease severity of soils in Canada [16]. Soil amendments which reduced Mn availability such as liming and nitrate fertilizers also increased the severity of CS [57]. Furthermore, direct Mn soil applications reduced the common scab of potato, especially when manganese sulfate was applied to Mn-deficient soils [58]. However, Barnes [59] found no effect on CS incidence when up to $125 \mathrm{~kg} / \mathrm{ha}$ of $\mathrm{MnSO}_{4}$ was applied on tubers or sprayed at tuber initiation (Table 1).

The availability of manganese depends on soil acidity. However, in soil, not only may limitation occur, but sometimes, a level toxic to plants was observed at some locations $[57,60,61]$. Yet more often, $\mathrm{Mn}$ is deficient, and that is connected with the increasing severity of various plant diseases.

In the plant, Mn serves as a co-factor of various enzymatic activities at low concentrations, while at high concentrations, it acts as their inhibitor [57]. Above that, Mn deficiency leads to an inhibition of cell elongation and decrease in tuber yield [61]. Thus, Mn limitation not only affects the overall growth of plants but also the thickness of the cell wall, which serves as protection for pathogen invasion [6]. Finally, Mn may affect the disease resistance of plants by controlling lignin and suberin biosynthesis, phenol biosynthesis and photosynthesis $[5,41,62]$.

Limitation of Mn may not be related only to its availability in soil. Since Mn is required at much higher concentrations by higher plants compared to fungi or bacteria, some pathogens are known to exploit this difference in requirement [63]. For example, some plant pathogens, including S. scabiei oxidize Mn, making it unavailable for the plant host and, thus, increasing the plant stress [64].

Consequently, Mn limitation may strongly affect disease control and should be assessed when macronutrients are in balance. The form of supplementation might be evaluated based on soil $\mathrm{pH}$ and organic matter content because both inorganic and organic forms can be applied for the improvement of Mn availability. Some organic amendments such as dried grass meal may also increase the number of manganese-reducing microorganisms [65] which make manganese available to plants. 
Table 1. Mineral nutrients availability in relation to common scab (CS) development.

\begin{tabular}{|c|c|c|c|c|c|}
\hline Element & $\begin{array}{c}\text { Factors of Availability to } \\
\text { Plants }\end{array}$ & Function in Plant & $\begin{array}{c}\text { Relation to Plant } \\
\text { Defense/Pathogenesis in General }\end{array}$ & Possible Relation to CS & Main References \\
\hline $\begin{array}{l}\text { Cation Exchange Capacity } \\
\text { (CEC) }\end{array}$ & $\begin{array}{l}\text { Higher CEC in clay than } \\
\text { sandy soils; low CEC and Ca } \\
\text { especially correlated with low } \\
\text { pH }\end{array}$ & $\begin{array}{l}\text { A measure of soil capacity to } \\
\text { hold nutrients }(\mathrm{Ca}, \mathrm{Mg}, \mathrm{K}, \mathrm{Na} \text {, } \\
\mathrm{Al} \text { and } \mathrm{H})\end{array}$ & $\begin{array}{l}\text { Different effects of } \mathrm{Ca}, \mathrm{Mg}, \mathrm{K} \text { and } \\
\text { their ratio; } \\
\text { imbalanced nutrients promote } \\
\text { impaired biosynthesis and } \\
\text { accumulation of low-molecular } \\
\text { weight substances readily available } \\
\text { for parasites }\end{array}$ & $\begin{array}{l}\text { CS disease severity related to } \\
\text { exchangeable } \mathrm{Ca}, \mathrm{Mg} \text { and } \mathrm{K} \\
\text { cations; } \mathrm{CEC} \text { is lower in } \\
\text { suppressive soil; the higher } \\
\mathrm{CEC} \text {, the greater uptake of } \\
\mathrm{Ca}^{2+} \text {; uptake of monovalent } \\
\text { cations }\left(\mathrm{K}^{+}\right) \text {increases at } \\
\text { lower } \mathrm{CEC}\end{array}$ & {$[5,37,60,66]$} \\
\hline K & $\begin{array}{l}\text { Leached out in acid soils; } \mathrm{Al} \\
\text { dominates the CEC, limits the } \\
\text { soil's ability to absorb and } \\
\text { hold K }\end{array}$ & $\begin{array}{l}\text { Control of cation-anion } \\
\text { homeostasis, membrane } \\
\text { polarization, more than } 60 \\
\text { enzymes in photosynthesis } \\
\text { and transport of } \\
\text { photosynthetic products to } \\
\text { storage organs; starch } \\
\text { synthesis; increased plant } \\
\text { resistance to pests, diseases } \\
\text { and abiotic stresses }\end{array}$ & $\begin{array}{l}\text { Correlated with } \mathrm{K}: \mathrm{Mg}, \mathrm{K}: \mathrm{Ca} \text { and } \mathrm{K}: \mathrm{N} \\
\text { ratios; decrease in some plant } \\
\text { diseases if } \mathrm{N} \text { and } \mathrm{P} \text { are sufficient; } \\
\text { high content of } \mathrm{N} \text { increases plant } \\
\text { susceptibility to diseases-this } \\
\text { adverse effect can be neutralized by } \\
\text { balanced } \mathrm{N}: \mathrm{K} \text { ratios of fertilizers }\end{array}$ & $\begin{array}{l}\text { Special Ca:K ratio reduces } \\
\text { scab severity and incidence, } \\
\text { while the imbalance or excess } \\
\text { of K or Ca promotes the } \\
\text { disease }\end{array}$ & {$[38,40,64,66]$} \\
\hline $\mathrm{Ca}$ & $\mathrm{pH}$ & $\begin{array}{l}\text { Stability and function of } \\
\text { membranes and cell walls; } \\
\text { second messenger triggered } \\
\text { by different stimuli including } \\
\text { pathogens }\end{array}$ & $\begin{array}{l}\text { At low Ca level, cells leak } \\
\text { compounds used as food by } \\
\text { parasites; supports some pathogens } \\
\text { by stimulating the action of } \\
\text { pectolytic enzymes dissolving plant } \\
\text { cell wall; inhibits the activity of other } \\
\text { pectolytic enzymes }\end{array}$ & $\begin{array}{l}\text { Ca may simulate the aerial } \\
\text { mycelium formation and } \\
\text { spore germination of } S \text {. } \\
\text { scabiei; high calcium levels in } \\
\text { the absence of changes in } \mathrm{pH} \\
\text { induce scab }\end{array}$ & {$[35,40,41,66]$} \\
\hline $\mathrm{Mg}$ & $\begin{array}{l}\text { Mg deficiency can be induced } \\
\text { by higher K supply }\end{array}$ & $\begin{array}{l}\text { Allosteric activator of more } \\
\text { than } 300 \text { enzymes; a central } \\
\text { part of chlorophyll molecules; } \\
\text { in the structural integrity of } \\
\text { cell components }\end{array}$ & $\begin{array}{l}\text { Decreases the susceptibility to } \\
\text { pathogen-produced macerating } \\
\text { enzymes as long as Ca level remains } \\
\text { sufficient }\end{array}$ & $\begin{array}{l}\text { Soils suppressive to CS } \\
\text { disease had a higher content } \\
\text { of } \mathrm{Mg} \text {; the CS-resistant potato } \\
\text { cultivar has a higher } \mathrm{Mg} \\
\text { content in periderm }\end{array}$ & {$[27,28,40,53]$} \\
\hline
\end{tabular}


Table 1. Cont.

\begin{tabular}{|c|c|c|c|c|c|}
\hline Element & $\begin{array}{c}\text { Factors of Availability to } \\
\text { Plants }\end{array}$ & Function in Plant & $\begin{array}{l}\text { Relation to Plant } \\
\text { Defense/Pathogenesis in General }\end{array}$ & Possible Relation to CS & Main References \\
\hline $\mathrm{Mn}$ & $\begin{array}{l}\text { More available with lower } \\
\text { pH; Mn uptake increased by } \\
\text { seed inoculation with } \\
\text { pseudomonads, organic } \\
\text { amendments increased } \\
\text { Mn-reducing microorganisms }\end{array}$ & $\begin{array}{l}\text { Co-factor of enzymatic } \\
\text { activity/an inhibitor at high } \\
\text { concentrations; control of } \\
\text { lignin and suberin } \\
\text { biosynthesis, phenol } \\
\text { biosynthesis, photosynthesis }\end{array}$ & $\begin{array}{l}\text { Mn is required at much higher } \\
\text { concentrations by higher plants than } \\
\text { by fungi and bacteria }\end{array}$ & $\begin{array}{l}\text { High Mn correlates with low } \\
\text { CS; S. scabiei oxidize Mn } \\
\text { making it unavailable for the } \\
\text { plant; soil amendments } \\
\text { reducing Mn availability } \\
\text { (liming, nitrate fertilizers) } \\
\text { increase CS severity; } \\
\text { herbicide glyphosate, toxic to } \\
\text { Mn reducing organisms }\end{array}$ & {$[55,57]$} \\
\hline $\mathbf{F e}$ & $\begin{array}{l}\text { Predominant ferric ion }\left(\mathrm{Fe}^{+3}\right) \\
\text { is sparingly soluble; more } \\
\text { available at lower } \mathrm{pH} \text { as } \\
\text { reduced form } \mathrm{Fe}^{+2} \text {; bacteria } \\
\text { supply iron to plants and } \\
\text { backward }\end{array}$ & $\begin{array}{l}\text { DNA synthesis, respiration, } \\
\text { photosynthesis; in prosthetic } \\
\text { groups of many enzymes } \\
\text { (cytochromes); synthesis of } \\
\text { chlorophyll; essential for } \\
\text { maintenance of chloroplast } \\
\text { structure and function }\end{array}$ & $\begin{array}{l}\text { Plants, bacteria and fungi compete } \\
\text { for Fe in the rhizosphere; } \\
\text { microorganisms have lower Fe } \\
\text { requirements than plants; promotes } \\
\text { antifungals' production by soil } \\
\text { bacteria for plant benefit; activates } \\
\text { both enzymes involved in the } \\
\text { infection and in plant defense }\end{array}$ & $\begin{array}{l}\text { S. scabiei produces } \\
\text { siderophores } \\
\text { desferrioxamine, scabichelin } \\
\text { and pyochelin to compete for } \\
\text { iron; lower CS severity in } \\
\text { soils with more available iron; } \\
\text { higher Fe in the periderm of } \\
\text { tubers grown in suppressive } \\
\text { soil; enrichment with } \\
\text { available iron and peat } \\
\text { suppressed CS }\end{array}$ & {$[5,27,33,67-70]$} \\
\hline
\end{tabular}




\subsubsection{Iron $(\mathrm{Fe})$}

In CS-suppressive soils, potatoes were less affected due to the available iron [33]. Furthermore, the concentration of Fe in the periderm of potato tubers grown in CS-suppressive soils significantly increased during the maturation period, whereas in conductive soils, it slightly decreased [36]. Overall, although cultivars differ in Fe requirements [71], the Fe content in various cultivars was usually not related to the CS disease [44]. Finally, the enrichment of soil with soluble iron (directly or through a decrease in soil $\mathrm{pH}$ by peat amendments) suppressed the CS severity, although the abundance of thaxtomin biosynthetic gene copies ( $t x t B$ genes) remained the same in the soil. This indicates that iron supports plant defense and reduces pathogen virulence rather than eliminating the pathogen population $[27,33]$ (Table 1).

Although iron is the fourth most abundant element on Earth, it is not readily assimilated by either bacteria or plants in aerobic soils because its oxidized form, $\mathrm{Fe}^{3+}$, is only sparingly soluble. Plant availability of Fe is also greatly reduced in calcareous soils $(\mathrm{pH}>7)$ [7]. That is in contrast with requirements of high iron levels by both microorganisms and plants. It is particularly problematic in the rhizosphere, where plants, bacteria and fungi compete for it [69]. Plants have developed two strategies for iron uptake: (1) mostly dicots acidify the rhizosphere by the production of organic acids and phenolic compounds to activate ferric chelate reductase and $\mathrm{Fe}^{2+}$ transporters; while (2) monocots produce phytosiderophores and respective transporters [69]. Bacteria have developed similar strategies of producing organic acids and synthesizing low-molecular-mass siderophores ( 400-1500 Da), molecules with a high affinity for $\mathrm{Fe}^{3+}$ as well as membrane receptors able to bind the Fe-siderophore complexes [72]. Many plant pathogens, including S. scabiei, use chelating compounds during iron uptake, and those can act as essential virulence determinants by limiting the plant's access to iron. S. scabiei produces three types of siderophores: desferrioxamine, scabichelin and pyochelin [73,74] (Table 1).

The effect of iron deficiency is critical for plants in metabolic processes such as DNA synthesis, respiration and photosynthesis because it serves as a co-factor of many enzymes, such as cytochromes of the electron transport chain. It is involved in the synthesis of chlorophyll and is essential for the maintenance of chloroplast structure and function [67]. Additionally, iron may participate directly in the activation of enzymes involved in infection as well as those involved in plant defense [75]. In addition, the availability of iron is important for the protective microbial community because it is required for the production of biocontrol metabolites, which may suppress various diseases [22].

The availability of iron seems to be the most overlooked factor in the protection of potato plants from different diseases, but particularly CS, because the pathogenic streptomycetes are well equipped for competition with the plants for iron supplies. The deficiency is likely in all alkaline soils but also in soils with low microbial activities. Thus, the availability of iron can be improved by supplementation with organic matter which increases microbial activities but also by fertilization by organically bound iron.

\subsection{Macronutrients}

Even though macronutrients are not in the main focus of CS disease control, nitrogen, phosphorus and potassium are often limiting factors and have also been demonstrated to affect CS severity, despite their regular amendments to arable soils. Similarly to micronutrients, particularly their balanced soil contents and availability are important because of many common interactions [5].

\subsubsection{Nitrogen $(\mathrm{N})$}

Most soils are poor in nitrogen, so it is generally supplied; yet its local recycling is often overlooked. The soil nitrogen pool is mostly replenished by ammonium released from dead biomass by microbial decomposers in natural conditions [76,77] and from the atmosphere by nitrogen fixation by symbiotic bacteria [78] or free-living bacteria and archaea [79]. The processes are attenuated by fertilizers containing large amounts of nitrogen. To 
understand local nitrogen status, the proportion of ammonia-oxidizing bacteria to archaea in the rhizosphere represents a potential bioindicator because it correlates with soil health status [80]. In addition, nitrogen-rich rocks occurring at some locations should not be overlooked because they offer a potentially large pool of nitrogen, and thus, no fertilization is required [81].

In CS, some studies showed that adding N-rich soy meal, meat and bone meal to soil led to an increase in ammonia, nitrite, nitrate, $\mathrm{pH}$ and bacterial quantity and suppressed CS [82]. Furthermore, the temporary initial increase in soil $\mathrm{pH}$ to eight or higher by the addition of organic materials resulted in an increase in free ammonium levels that might be toxic to populations of S. scabies [83]. It was also shown that oligotrophic conditions of low soil $\mathrm{C}$ and $\mathrm{N}$ are associated with $\mathrm{CS}$ control, possibly because the low $\mathrm{N}$ content constrains the pathogens, favoring copiotrophic soil conditions [27].

The observed differences in nitrogen's impact on CS may be the result of a partially different utilization by potato cultivars [84]. A high content of $\mathrm{N}$ is known to increase the plant susceptibility to several diseases, but the adverse effect can be neutralized by balanced $\mathrm{N}: \mathrm{K}$ ratios of fertilizers [66].

Thus, soil N content should be checked for balance with other nutrients, and fertilization by nitrogen should be evaluated carefully for CS control so as not to eliminate microbial activities. Furthermore, ammonium levels may be important indicators of microbial processes relevant to CS control.

\subsubsection{Phosphorus (P)}

The relationship of soil P to CS has been studied for a long time. Recently, a high soil phosphorus content was observed in CS-suppressive fields [27], and CS severity was negatively correlated with the total phosphorus content in both soil and potato periderm $[32,44]$. Similar to other nutrients, there is a combination of the nutrient's effects on the plant and the pathogen, which need to be disentangled to suggest an appropriate strategy for CS control.

Ecosystems begin their existence with a fixed amount of $\mathrm{P}$, which cannot be readily replenished. Consequently, ecosystems with very old soils can become P-limited [2]. P in soil is subject to an extensive set of physico-chemical and biological reactions, while only a small part of total soil $\mathrm{P}$ is in a biologically available form [85]. In particular, in calcareous soils, precipitation of calcium phosphate is presumed to be a major factor in the loss of $\mathrm{P}$ availability over time [86]. As one of six macroelements, phosphorus is directly involved in all processes in the plant. Additionally, potatoes have a relatively high $\mathrm{P}$ requirement but are rather inefficient in soil P uptake [34], so deficiency is likely to occur.

In the plant, phosphorus deficiency results in a broad range of stress and adaptation responses [87], including changes in the root system morphology and increased expression of phosphoenolpyruvate carboxylase, resulting in root exudation of organic acids, which changes $\mathrm{P}$ equilibrium in the plant rhizosphere and may influence the development of specific microbial groups, including pathogens [88]. Similarly, phosphate-solubilizing microorganisms, e.g., the genera Bacillus, Pseudomonas, Agrobacterium, Acetobacter, Streptomyces and Nocardia, release P from parent rocks and other sparingly soluble forms of soil $\mathrm{P}$ by secreting organic acids, and during the process, they decrease the particle size [66]. Yet, microbial communities differ by $\mathrm{P}$ release, possibly also due to a pressure by predators, which speeds up its recycling. This was suggested as a partial mechanism in some disease-suppressive soils [14].

However, it was observed that the content of available soil $\mathrm{P}$ is related to the amounts of carbon, lignin, cellulose, polyphenol and nitrogen. For this reason, their quantities may be used as predictors of the P release in various soils [86].

To assist the optimal P levels for CS disease control, solubilization activities by microorganisms can be supported by an increase in organic matter, particularly if it is slightly acidic. Selection of potato cultivars with higher capacity of $\mathrm{P}$ uptake is also recommended because potato cultivars vary in the efficiency of P utilization [44]. 


\subsubsection{Potassium}

Potassium has the highest concentrations in potato tubers out of all macronutrients [40, 62] but the impact of its content on CS varies greatly. Potassium concentration measured in the tuber periderm was not related to CS occurrence or severity in various potato cultivars [36]. Yet in other studies, CS severity positively correlated with the available soil $\mathrm{K}$ content [16], and CS was less severe in soils with a relatively high concentration of exchangeable $\mathrm{Ca}, \mathrm{Mg}$ and $\mathrm{K}$ [37].

The sources of potassium are minerals-feldspars and micas-which release this element in the course of their weathering. Weathered potassium appears in solution as an exchangeable ion, $\mathrm{K}^{+}$, which is adsorbed to or released from surfaces of clay particles or organic matter [89]. Therefore, the presence of K-rich minerals and soil clay content needs to be considered before its supplementation. Similar to other nutrients, K-solubilizing microorganisms assist its availability, so their enrichment may benefit plants in soils where $\mathrm{K}$ is present but not in forms available to plants [90].

Similar to other macronutrients, potassium in plants controls major pathways such as cation-anion homeostasis, membrane polarization and enzymatic activity [40]. $\mathrm{K}$ is also involved in more than 60 enzymes participating in photosynthesis, moving photosynthetic products to storage organs such as seeds and tubers [66] and starch synthesis [40]. K plays an important role in increasing plant resistance to pests, diseases and abiotic stresses [66]. Its deficiency leads to impaired synthesis of high-molecular-weight compounds (proteins, starch and cellulose), while low-molecular-weight organic compounds accumulate and are easily available to the invading plant pathogens [5].

Potassium's equilibrium with other macronutrients is particularly important for the prevention of CS. However, cultivars with a higher K uptake may be also selected to prevent $\mathrm{K}$ limitation because various cultivars differ strongly in $\mathrm{K}$ accumulation [44].

\section{Organic Matter Modifies Microbial Communities and Increases Antibiosis}

The application of organic amendments to soil was proposed as a strategy for the management of diseases caused by soil-borne pathogens [91]. Soil organic matter (SOM) supplementation can produce suppressive soils on which pathogens do not establish or persist $[92,93]$. Though many attempts have been made to suppress various plant diseases, they have generally been met with varied success [91,94].

Many studies showed also CS reductions with the addition of various organic materials, including compost [95], peat [33], green manure [92,96], several types of animal manure $[83,97,98]$ and fish emulsion [21] (Table 2). Although the effect of organic amendments was found to be mostly beneficial, rarely were the causes for the observed effects on CS (intensification or suppression) resolved. It seems that the results depend on the organic matter quality but also on the period and frequency of application [98,99]. Therefore, a more precise understanding of organic matter supplementation is needed for successful CS control.

Currently known mechanisms of SOM impact on the development of plant diseases include (1) decrease in soil pH and increase in nutrient availability [100], (2) improvement of soil nutrient-holding capacity and stability [101] and (3) disease-suppressive activities of soil microbial communities [22]. Regarding CS specifically, direct suppression of the pathogen S. scabies by harmful organic compounds was achieved by fertilization with chestnut waste [102]. Finally, the connection between CS severity and SOM content may be explained by the preferential food hypothesis, according to which carbon substratedeprived Streptomyces develop a pathogenic tendency, while their usual lifestyle is benign and saprophytic [103]. 
Table 2. Effects of organic matter amendments on incidence and severity of potato common scab.

\begin{tabular}{|c|c|c|c|c|}
\hline Material & Quantity & Method & Effect & Reference \\
\hline Compost & $0.4 \mathrm{mt} \mathrm{ha}^{-1}$ & & CS suppression $42 \%$ & [95] \\
\hline Aerobic compost tea & $140 \mathrm{~L} \mathrm{ha}^{-1}$ & Back-pack sprayer & CS suppression $81 \%$ & \\
\hline $\begin{array}{l}\text { Indian mustard green } \\
\text { manure }\end{array}$ & & $\begin{array}{l}\text { In the year before } \\
\text { potatoes }\end{array}$ & CS suppression $25 \%$ & [96] \\
\hline $\begin{array}{l}\text { Barley/ryegrass } \\
\text { rotations }\end{array}$ & & $\begin{array}{l}\text { Rotated prior to } \\
\text { potatoes }\end{array}$ & CS suppression $13-34 \%$ & [104] \\
\hline $\begin{array}{l}\text { Lopsided oat (Avena } \\
\text { strigosa) }\end{array}$ & $150 \mathrm{~kg} \mathrm{ha}^{-1}$ & $\begin{array}{l}\text { Rotovator prior to } \\
\text { potatoes }\end{array}$ & CS suppression & [105] \\
\hline Rice bran & 3 tha $^{-1}$ & $\begin{array}{l}\text { In the furrow with the } \\
\text { seed tubers }\end{array}$ & CS suppression (DS) & [106] \\
\hline $\begin{array}{l}\text { Soybean green manure, } \\
\text { with wheat straw }\end{array}$ & & $\begin{array}{l}\text { Incorporated before } \\
\text { planting }\end{array}$ & CS suppression & [107] \\
\hline $\begin{array}{c}\text { Green manure (Brassica } \\
\text { napus) }\end{array}$ & & $\begin{array}{l}\text { Grown for approx. } \\
2 \text { months in the fall }\end{array}$ & $\begin{array}{l}\text { Decrease in CS incidence and } \\
\text { severity }\end{array}$ & [92] \\
\hline Compost & $2.5 \mathrm{~kg} \mathrm{~m}^{-2}$ & 5 days before planting & $\begin{array}{l}\text { CS suppression: } 61 \% \text { to } 28 \% \\
\text { DI, } 30 \% \text { to } 16 \% \text { DS a }\end{array}$ & [108] \\
\hline Compost tea & $1 \mathrm{~kg} \mathrm{~m}^{-2}$ in $5 \mathrm{~L}$ water & Soil drenching & $\begin{array}{l}\text { CS suppression: } 61 \% \text { to } 32 \% \\
\text { DI, } 30 \% \text { to } 15 \% \text { DS }\end{array}$ & \\
\hline Fish emulsion & $1 \%$ & Soil amendment & No effect & [21] \\
\hline $\begin{array}{l}\text { Processed swine } \\
\text { manure }\end{array}$ & $2 \mathrm{~g}$ per seed & Seed covering & Increased DI & [109] \\
\hline $\begin{array}{l}\text { Processed swine } \\
\text { manure with chitosan }\end{array}$ & $\begin{array}{l}2 \text { g per seed; } 1 \% \\
\text { chitosan }\end{array}$ & Seed covering & no effect & \\
\hline Chicken manure & $66 \mathrm{tha}^{-1}$ & $\begin{array}{l}\text { Incorporated to } 15-\mathrm{cm} \\
\text { depth }\end{array}$ & CS suppression & [83] \\
\hline Swine manure & $5.5 \mathrm{~m}^{3} \mathrm{ha}^{-1}$ & & CS suppression & \\
\hline Dairy cattle manure & $100 \mathrm{t} \mathrm{ha}^{-1}$ & & No effect & \\
\hline Poultry manure & $1.54-12.32 \mathrm{Mg} \mathrm{C} \mathrm{ha}^{-1}$ & $\begin{array}{l}\text { Applied dehydrated, } \\
\text { pelletized prior to } \\
\text { planting potatoes }\end{array}$ & CS suppression & [98] \\
\hline $\begin{array}{c}\text { Poultry manure, } \\
\text { forestry residues and } \\
\text { organic waste compost }\end{array}$ & $45 \mathrm{Mg} \mathrm{ha}^{-1}$ & $\begin{array}{l}\text { Incorporated to a depth } \\
\text { of } 15 \mathrm{~cm} \text { in October, a } \\
\text { year before planting }\end{array}$ & CS suppression & [97] \\
\hline Meat and bone meal & $37 \mathrm{tha}^{-1}$ & $\begin{array}{l}\text { Incorporated to } 15-\mathrm{cm} \\
\text { depth }\end{array}$ & CS suppression & [16] \\
\hline Soymeal & $37 \mathrm{tha}^{-1}$ & & CS suppression & \\
\hline Poultry manure & $66 \mathrm{tha}^{-1}$ & & CS suppression & \\
\hline Poultry manure & $20 \mathrm{tha}^{-1}$ & & No effect & \\
\hline $\begin{array}{l}\text { Nature Safe } 10-2-8 \\
\text { (poultry feathers) }\end{array}$ & $10 \mathrm{tha}^{-1}$ & & CS suppression by $50-100 \%$ & \\
\hline $\begin{array}{l}\text { Ammonium } \\
\text { lignosulfonate }\end{array}$ & $1000 \mathrm{~L} \mathrm{ha}^{-1}$ & & $\begin{array}{c}\text { Marketable yield } 60-80 \% \\
\text { compared to } 10 \% \text { in the control }\end{array}$ & \\
\hline Peat & $2.5 \mathrm{~L}$ peat /10 L soil & In submerged pots & CS suppression & [33] \\
\hline
\end{tabular}

${ }^{a}$ DS—disease severity (percentage of surface covered with lesions); DI—disease incidence (proportion of infected tubers). 
Green manures seem to particularly affect the availability of nutrients such as $\mathrm{P}, \mathrm{Mn}$ and $\mathrm{Zn}$, which are related to plant defense [91,110]. The application of peat or other low-N, low-pH SOM may also result in solubilization of nutrients, particularly Fe, but also other metals. The additions of low-pH SOM can be also followed by shifts of microbial community composition towards the increase in suppressive activities [33,91]. Green manures combined with appropriate crop rotation may also increase the protective streptomycetes soil sub-community $[5,104,111]$.

Soil suppressiveness reinforced by activities of microbial communities was observed after addition of older compost, aerobic compost tea [95], decomposed wheat straw or soybeans [107], lopsided oat [105] or rice bran [106]. Those manipulations were later connected to increased lignin content, which can induce the production of secondary metabolites controlling the pathogen [112].

As efficient soil saprophytes, streptomycetes are especially likely to respond to the incorporation of organic material into the soil and are often implicated as microbial agents responsible for amendment-induced suppression [106,113]. This was demonstrated by organic amendments, which enriched, especially, some Streptomyces populations $[113,114]$, but also with actinobacteria isolates derived from the rice bran-amended soil, which showed antagonistic activity against pathogenic S. scabiei and S. turgidiscabies [106] (Table 2). However, the use of antibiotic-resistant S. scabies mutants indicated that some streptomycetes strains can reduce pathogen populations even when they are not sensitive to antibiotic inhibition. It demonstrated that competition by non-pathogenic streptomycetes for space and resources rather than antibiotic activities efficiently eliminates Streptomyces pathogens by competitive exclusion. Thus, both antibiotic inhibition and competition between pathogenic and non-pathogenic Streptomyces are likely to be important mechanisms of natural suppression of potato scab [29].

In contrast, increased CS severity and/or incidence was observed after fertilization with fresh animal manure but also with compost [91,99]. In another study, CS-suppressive and -conducive soils were discriminated by specific low-molecular-weight organic compounds [27,115]. Finally, in the same study, the quantity of CS pathogens (thaxtomin biosynthetic gene $t x t B$ copies) was positively correlated with the soil total $C$ and $\mathrm{N}$ contents, whose proportion approximates the type of SOM and its degradability by soil microorganisms [27].

It was suggested that CS pathogens can persist in soil for many years, surviving on decaying plant debris, especially where heavy loads of animal manure were applied [116], and that they possibly survive there by feeding on oligosaccharides released by ligninolytic and cellulolytic microorganisms $[117,118]$. This "cheating" behavior of CS pathogens suggests that competitive relationships may occur between them and ligninolytic or cellulolytic streptomycetes. The intensity of the competition might be dependent on the quality of available SOM $[29,112,114]$. Some of these oligosaccharides also act as environmental signals to plant pathogenic Streptomyces inducing the production of thaxtomin [117] so that they may further support their pathogenicity, but the regulation of those pathways is not completely resolved [119].

The inconsistent effects of various SOM additions on CS severity and incidence together with the knowledge on the importance of different carbohydrates in the induction of specific metabolic pathways in both pathogenic and beneficial streptomycetes suggest that a more precise SOM characterization is needed in future research, because only gross measurements have been provided for field testing so far [115]. Thus, we propose that organic matter supplements containing oligo- and monosaccharides should be avoided, while fresh low-pH SOM will help in nutrient release, and older, more decomposed SOM will benefit activities of antagonistic streptomycetes.

\section{Rhizosphere Microorganisms Influence Nutrient Recycling and Produce Beneficial Metabolites}

Microbial communities of the crop rhizosphere are essential not only for plant nutrition and health but also for nutrient cycling in agroecosystems. Therefore, there is a need to link 
soil properties, especially the content and character of organic matter, with the distribution and activity of microorganisms and their use in plant protection.

Soil type and $\mathrm{pH}$ exert the most profound influence on the structure and function of bacterial communities [120]. In the rhizosphere, microbial communities are additionally shaped by the plant through its root exudates [121-124]. In return, the rhizosphere and also soil-derived endophytic microorganisms support the plant growth, health and metabolism [125]. The main activities of these plant-associated microorganisms are related to recycling of nutrients through mineralization of root exudates, nitrogen fixation or solubilization of minerals. Some microbes may also produce plant hormones and increase root growth [55]. This interaction is particularly important in plant management strategies because the population density of microorganisms in the rhizosphere is several times greater than that in bulk soil [126].

The composition of microbial communities in the rhizosphere is also influenced by the invasion of pathogens, which poses consequences not only for the particular disease but also for the functioning of the whole community [127]. Then, suppressive soils may act differently than conducive soils with respect to microbial community changes [22,28]. Furthermore, the suppressive effect is differentiated between induced suppressive soils of long-term monoculture and natural suppressive soils that undergo regular crop rotation $[27,31,128,129]$.

Induced suppressive soils for CS contained a higher proportion of Acetobacteraceae, Bacillaceae and Lysobacter (Xanthomonadaceae) but also non-pathogenic Streptomyces (Actinobacteria) and lower proportions of some Acidobacteria, Nocardioidaceae and Pseudomonadaceae [130]. The naturally suppressive soils were enriched in Pseudomonadaceae, Bradyrhizobiaceae, Acetobacteraceae and Paenibacillaceae, which are all families of known plant growthpromoting microbes [28]. Some of the taxa occurring in suppressive soils were also enriched in soils supplemented with organic matter, which also led to CS suppression. These include Bacillus, Streptomyces [106] as well as Solirubrobacteraceae, Xanthomonadaceae and Sphingomonadaceae [33] (Table 3).

The suppressivity of soils is not only connected to the bottom-up control of the microbial communities, which is represented by soil physical characteristics [131], contents of nutrients (e.g., [27,33]), production of plant hormones [132] and organic matter quality [97], because the second half of the story is the top-down control by a range of bacterial and eukaryotic consumers and predators. Furthermore, predation by protists is also considered the missing link to understand soil suppressiveness because they are increasingly recognized as an essential component in nutrient recycling, shaping plant physiology, nutrition and health [14]. Those findings come from experiments conducted in controlled environments, where protists could influence the disease-suppressive ability of microbial communities directly by decreasing their numbers or via changes in the community composition [133]. Regarding CS, the micro-eukaryotic community was enriched with Chlorophyta together with Myxogastria, Apicomplexa and Ciliophora in CS-conducive soil, which consequently displayed increased micro-eukaryotic diversity and a higher number of putative interactions. Furthermore, micro-eukaryotic community was correlated with soil $\mathrm{pH}$ and contents of C, N, P, Ca and Fe in conducive soil but with $\mathrm{S}$ content in suppressive soil [28]. Thus, although the results are only preliminary, it seems that not only nutrient cycling and plant nutrition but also disease protection may be affected by trophic relationships [134].

Modification of plant-associated microbial communities can be achieved by planting various cultivars, because their tuberospheres are inhabited by cultivar-specific bacterial communities, which also comply with the cultivars' resistance to CS [28,135]. For example, Nitrospirae and Acidobacteria were enriched in a resistant cultivar together with a decreased ratio of Thaumarchaeota/Euryarchaeota. Out of these, Nitrospirae and Thaumarchaeota belong among important nitrifiers and ammonia-oxidizers, respectively, which points to their connection with nitrogen cycling. The increase in Acidobacteria suggests that a decrease in $\mathrm{pH}$ and an increase in Euryarchaeota points to the modification of $\mathrm{pH}$, moisture or the carbon cycle $[28,136]$. In another study, microbial communities associated with resistant 
cultivars exhibited lower abundance of bacteria, higher diversity, higher co-occurrence network complexity and increased community functioning.

Table 3. Microbial community changes associated with lowered CS severity due to soil suppressivity, potato cultivar or soil amendment.

\begin{tabular}{|c|c|c|}
\hline Manipulation & Affected Bacterial Groups & Reference \\
\hline Suppressive soil & $\begin{array}{c}\text { Higher frequency of antagonistic pseudomonads and streptomycetes } \\
\text { and higher proportion of pathogenic streptomycetes by cultivation; } \\
\text { different microbial community by terminal restriction fragment } \\
\text { analysis }\end{array}$ & [137] \\
\hline Suppressive soil & $\begin{array}{c}\text { Higher proportion of Acetobacteraceae, Bacillaceae and Lysobacter } \\
\text { (Xanthomonadaceae), lower Acidobacteria group 6, Nocardioidaceae, } \\
\text { Pseudomonadaceae, unclassified Acidobacteria group } 11 \text { and unclassified } \\
\text { Bacilli }\end{array}$ & [130] \\
\hline Suppressive soil & $\begin{array}{l}\text { Enriched in Pseudomonadaceae, Bradyrhizobiaceae, Acetobacteraceae and } \\
\text { Paenibacillaceae; decreased ratio of Thaumarchaeota/Euryarchaeota in } \\
\text { tuberosphere of susceptible cultivar; higher proportions of } \\
\text { Ascomycota and Basidiomycota and lower proportions of } \\
\text { Chlorophyta, Ciliophora, Myxogastria and Apicomplexa }\end{array}$ & [28] \\
\hline Resistant cultivar & $\begin{array}{c}\text { Same as in suppressive soil and enriched in Nitrospirae and } \\
\text { Acidobacteria; decreased tuberosphere ratio of } \\
\text { Thaumarchaeota/Euryarchaeota in conducive soil; Chlorophyta and } \\
\text { Cercozoa in lower proportions }\end{array}$ & \\
\hline Resistant cultivar & More non-pathogenic streptomycetes than in susceptible cultivar & [138] \\
\hline Resistant cultivar & $\begin{array}{l}\text { Cloning/Sanger sequencing analysis of root, tuber and rhizosphere } \\
\text { bacterial communities of } 8 \text { cultivars differing in resistance to CS; } \\
\text { higher abundance of } S \text {. turgidiscabies in susceptible cultivars by qPCR }\end{array}$ & [30] \\
\hline Susceptible cultivar & $\begin{array}{l}\text { Variovorax, Stenotrophomonas and Agrobacterium were positively, and } \\
\text { Geobacillus, Curtobacterium and unclassified Geodermatophilaceae } \\
\text { negatively, correlated with the scab severity level, estimated absolute } \\
\text { abundance of pathogenic Streptomyces and } t x t A B \text { genes }\end{array}$ & [23] \\
\hline $\begin{array}{l}\text { Biocontrol strain Pseudomonas fluorescens } \\
\text { LBUM223 }\end{array}$ & $\begin{array}{l}\text { Inoculation does not significantly alter the autochthonous } \\
\text { rhizosphere nor geocaulosphere microbiomes in the field }\end{array}$ & [139] \\
\hline Rice bran amendment & $\begin{array}{c}\text { Bacillus, Streptomyces, Chitinophaga and Actinomadura significantly } \\
\text { increased; unclassified Koribacteraceae and unclassified Gaiellaceae were } \\
\text { significantly reduced }\end{array}$ & [106] \\
\hline Iron amendment & Bacillales and Gaiellales & [33] \\
\hline Peat amendment & Rhizobiales, Burkholderiales, Xanthomonadales and Bacillales & \\
\hline Peat and iron amendment & $\begin{array}{l}\text { Proteobacteria and Bacteroidetes increased at the proportional expense } \\
\text { of Actinobacteria; proteobacterial Burkholderiales, Xanthomonadales and } \\
\text { Sphingomonadales and actinobacterial order of Gaiellales were the most } \\
\text { responsive groups; actinobacterial families Micromonosporaceae and } \\
\text { Thermomonosporaceae were elevated }\end{array}$ & \\
\hline
\end{tabular}

Furthermore, a metagenomic approach showed that particularly the enrichment of antibiotic biosynthesis pathways within members of bacterial communities was typical for the tuberosphere soil of healthy tubers. In contrast, the tuberosphere soil of diseased tubers was enriched in Variovorax, Stenotrophomonas and Agrobacterium together with several ABC transporter genes, genes of bacterial secretion system, quorum sensing, cytochrome P450 and also genes for nitrogen metabolism [23]. Comparison between the metagenomes differently affected by the pathogen populations supports the previously mentioned observations that, in the vicinity of tubers, antibiosis and possibly also nitrogen-related process are important in CS disease control (Figure 1, Table 3). 


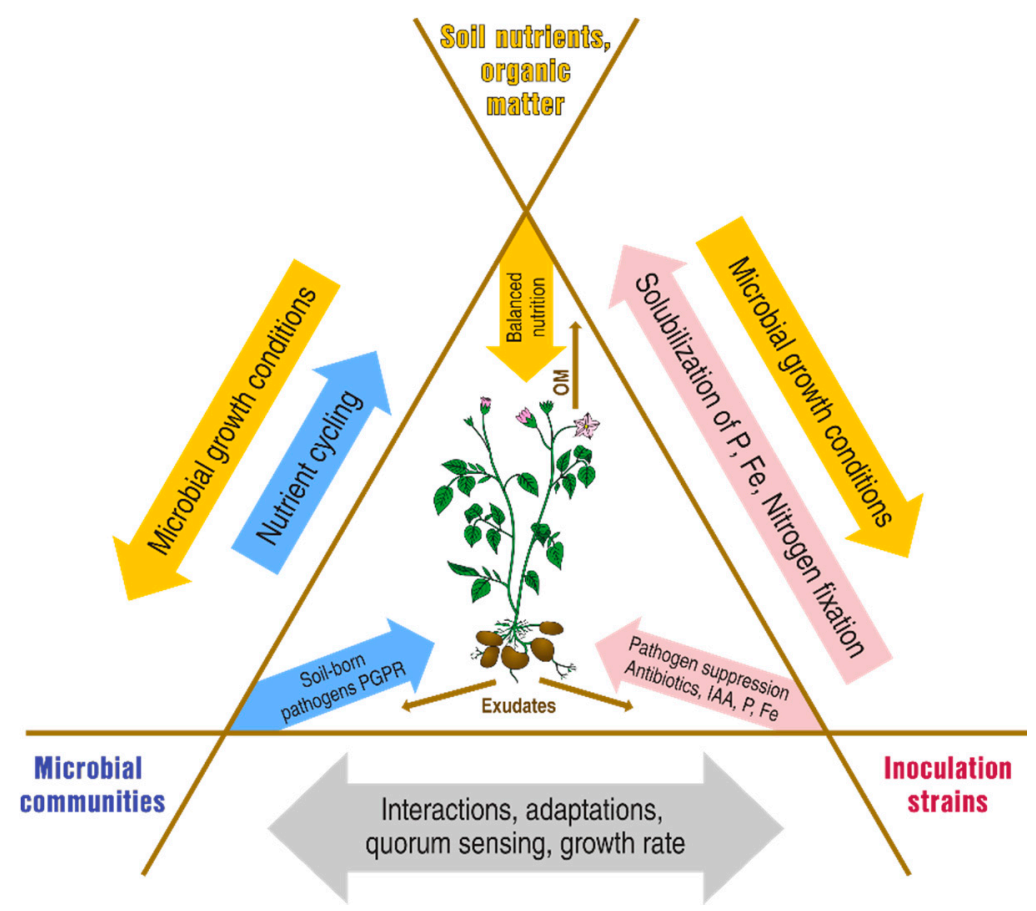

Figure 1. Interactions of soil components, microbial communities, introduced biocontrol strains and potato plants in a system affected by common scab.

The research also demonstrated that the plant-microbe interactions connected to CS severity are detectable only in the nearest vicinity to the potato tuber. In particular, out of the potato tuberosphere, rhizosphere, root zone or bulk soil, the effects of manipulations were detectable only in the tuberosphere soil $[23,28]$. That closely connects the soil and plant microbiomes, which seem to share not only members but also functions such as activation of both basal and inducible plant defense systems [25,140].

The changes in the microbial community associated with increased CS control might be achieved by addition of specific organic compounds, but also by addition of nutrients (see above).

Consequently, the current knowledge on microbial interactions in the rhizosphere is still limited in terms of being clearly resolved in terms of CS control. However, many examples of successful manipulation of microbial communities by supplementation or cultivars are already available to consider for the improvement of soil health.

\section{Inoculation with Antagonistic Strains}

Disease occurrence is often accompanied by changes in microbial communities such as altered microbial abundance, composition and function, which are studied as markers of soil health but also for their potential to set conditions favorable for plant protection. Various taxa participate in those activities, or their combinations [22,141].

CS-suppressive soils revealed that non-pathogenic Streptomyces act as the agents responsible for suppression $[129,130]$. However, different studies showed that a broad range of bacterial and fungal taxa contribute to CS suppression, with antagonistic activities found in strains of the genera Streptomyces [142-145], Bacillus [146,147], Brevibacillus [148] and Pseudomonas [149], and they were successfully used to control the disease in pot and field trials (Table 4).

Application of the individual strains or strains with organic or inorganic fertilization mostly resulted in significant decreases in CS severity (e.g., [143,144,147,150-155]). In a few studies, the suppression of pathogenic strains or the decrease in genes from the pathogenic island were also determined $[149,156]$. Surprisingly, in some studies, no effect on the autochthonous microbial community was observed after inoculation [111,139], while in others, proportions of several taxa were altered [146]. 
Table 4. Soil inoculation affecting CS severity, tuber yield and associated bacterial community.

\begin{tabular}{|c|c|c|}
\hline \multicolumn{3}{|c|}{ A. Complex Inocula } \\
\hline Inoculum & Effect & Reference \\
\hline Swine feces with coprophilous actinobacteria & $\begin{array}{l}\text { CS suppression; viable counts of Streptomyces scabies decreased, antagonistic } \\
\text { fluorescent pseudomonads increased }\end{array}$ & [156] \\
\hline $\begin{array}{l}\text { Broth treatment and inoculation with } \\
\text { antagonistic Bacillus sp. in pot assay with } \\
\text { sterile soil }\end{array}$ & CS suppression by $40 \%$ & [154] \\
\hline Pseudomonas mosselii with vermicompost & CS suppression & [150] \\
\hline $\begin{array}{l}\text { Bacillus subtilis GB03 and Rhizoctonia solani } \\
\text { hypovirulent isolate Rhs1A1, compost }\end{array}$ & $\begin{array}{l}\text { CS suppression by } 10-34 \% \text {, increased yield, reduction in stem and stolon } \\
\text { canker by } 20-38 \% \text {, black scurf by } 30-58 \%\end{array}$ & [151] \\
\hline $\begin{array}{l}\text { Trichoderma virens, Bacillus subtilis and } \\
\text { Rhizoctonia solani, compost, rapeseed rotation }\end{array}$ & Reduced disease and increased yield & [92] \\
\hline $\begin{array}{l}\text { Vermiculite cultures of non-pathogenic } \\
\text { Streptomyces isolates mixed with soil }\end{array}$ & CS suppression & [157] \\
\hline $\begin{array}{l}\text { Conducive soil inoculated with Streptomyces } \\
\text { isolates }\end{array}$ & $\begin{array}{l}\text { No effect of inoculation; variability of streptomycete community increasing } \\
\text { from planting to mid-season (by pyrosequencing); pathogen suppressive } \\
\text { capacity of antagonistic streptomycetes negatively correlating with CS } \\
\text { severity (by cultivation) }\end{array}$ & [111] \\
\hline \multicolumn{3}{|c|}{ B. Individual strains } \\
\hline Inoculum & Effect & Reference \\
\hline $\begin{array}{l}\text { Streptomyces melanosporofaciens } \\
\text { EF-76 in chitosan beads }\end{array}$ & $\begin{array}{l}\text { Increased numbers of geldanamycin-resistant actinobacteria on harvested } \\
\text { potato tubers }\end{array}$ & [142] \\
\hline $\begin{array}{l}\text { Pesticide and antibiotic-resistant Streptomyces } \\
\text { spp. }\end{array}$ & CS suppression by $55->60 \%$ & [144] \\
\hline S. violaceusniger $\mathrm{AC} 12 \mathrm{AB}$ & $\begin{array}{l}\text { CS reduction up to } 90 \% \text { in greenhouse and field, increased yield up to } 26.8 \% \\
\text { in field trial }\end{array}$ & [145] \\
\hline Streptomyces sp. WoRs-501 & CS severity decreased by $78-94 \%$ in field pot trial & [143] \\
\hline Streptomyces strain 272 & $\begin{array}{l}\text { CS severity reduced by } 43 \% \text { on susceptible potato cultivar Bintje, both disease } \\
\text { incidence and severity reduced by } 43 \text { and } 59 \% \text { on the scab-tolerant cultivar } \\
\text { Nicola }\end{array}$ & [158] \\
\hline $\begin{array}{l}\text { Pseudomonas fluorescens } \\
\text { LBUM223 }\end{array}$ & $\begin{array}{c}\text { CS reduced by approximately } 30 \% \text { in plots after biweekly applications, } \\
\text { increased yield by } 46 \% \text {; did not reduce pathogen soil populations, } \\
\text { down-regulated } t x t A \text { expression in the geocaulosphere }\end{array}$ & {$[149,159]$} \\
\hline $\begin{array}{l}\text { Bacillus megaterium KBA-10, P. putida K-19B, B. } \\
\text { megaterium TV- 91C, Pantoea agglomerans RK-92 }\end{array}$ & Biocontrol efficacy $18.7-60.3 \%$, tuber yield increase by $20.4-40 \%$ & [160] \\
\hline $\begin{array}{l}\text { B. subtilis and Trichoderma harzianum in } \\
\text { diatomaceous earth } \\
\left(225-300 \mathrm{~kg} \mathrm{ha}^{-1}\right)\end{array}$ & $\begin{array}{c}\text { CS index decreased by 30.6-46.1\%; 19-23-fold higher Pseudomonadales; CS } \\
\text { severity negatively correlated with relative abundances of Agrobacterium, } \\
\text { Achromobacter and Pseudomonas and positively with Acidobacteria, } \\
\text { Actinobacteria, Chloroflexi and Gemmatimonadetes }\end{array}$ & [146] \\
\hline Brevibacillus laterosporus AMCC100017 & $\begin{array}{l}\text { CS severity decreased from } 2.60 \text { to } 0.77 \text {, i.e., biocontrol efficacy } 70.51 \% \text {; } \\
\text { reduced pathogen, transient impact on the native bacteria community }\end{array}$ & [148] \\
\hline Bacillus subtilis & Decrease in common scab severity up to $70 \%$, and $67 \%$ in field trials & [147] \\
\hline B. amyloliquefaciens Ba01 & CS reduced from $14.4 \pm 2.9 \%$ (naturally occurring) to $5.6 \pm 1.1 \%$ in the field & [161] \\
\hline B. velezensis $8-4$ & $\begin{array}{l}\text { CS control efficiency reached } 51.83 \pm 8.53 \% \text {, the yield increased by } \\
\qquad 19.91 \pm 3.56 \%\end{array}$ & [155] \\
\hline Trichoderma virens & Decrease in CS incidence and severity & [92] \\
\hline Phages Stsc1 and Stsc3 & Prevented CS symptoms on radish seedlings & [162] \\
\hline
\end{tabular}


Table 4. Cont.

\begin{tabular}{|c|c|c|}
\hline \multicolumn{3}{|c|}{ C. Mechanisms of CS suppression } \\
\hline Biocontrol Strain & Observed Property & Reference \\
\hline $\begin{array}{l}\text { Streptomyces violaceusniger } \\
\text { AC12AB }\end{array}$ & $\begin{array}{l}\text { Production of azalomycin, indole-3-acetic acid and siderophores, nitrogen } \\
\text { fixation and phosphate solubilization => CS reduction up to } 90 \% \text { in } \\
\text { greenhouse and field trials, increased yield up to } 26.8 \% \text { in field trial }\end{array}$ & [145] \\
\hline \multirow[t]{2}{*}{$\begin{array}{l}\text { Pseudomonas fluorescens } \\
\text { LBUM223 }\end{array}$} & $\begin{array}{l}\text { Phenazine-1-carboxylic acid (PCA) production }=>\text { growth inhibition of } S \text {. } \\
\text { scabiei, repression of thaxtomin biosynthesis genes }(t x t A \text { and } t x t C) \text {; activities } \\
\text { were lost in } p h z C^{-} \text {mutant deficient in PCA production }\end{array}$ & [163] \\
\hline & $\begin{array}{l}\text { Phenazine-1-carboxylic acid production }=>12 \%-14 \% \text { of all } S \text {. scabiei genes } \\
\text { were differentially expressed, including key genes involved in } \\
\text { pathogenicity/virulence, mycelium differentiation and increased oxidative } \\
\text { stress }\end{array}$ & {$[164]$} \\
\hline $\begin{array}{l}\text { Fragments of } \gamma \text {-glutamyl transpeptidase from } \\
\text { Bacillus subtilis BU108 }\end{array}$ & In vitro growth inhibition of S. scabiei & [165] \\
\hline S. melanosporofaciens EF-76 & $\begin{array}{l}\text { Geldanamycin production }=>\text { disease index was reduced from } 6.30 \text { to } 4.81 \text { and } \\
\text { from } 2.83 \text { to } 2.49 \text { in growth chamber and field experiments, respectively }\end{array}$ & {$[166]$} \\
\hline Streptomyces A1RT & $\begin{array}{l}\text { Production of isatropolone } C \text { and indole-3-acetic acid }=>\text { reduction in average } \\
\text { disease severity index by } 82.4-95.7 \%\end{array}$ & {$[4]$} \\
\hline $\begin{array}{l}\text { Streptomyces isolates (strains } 93 \text { and } 63 \text { ) and } \\
\text { their spontaneous mutants }\end{array}$ & $\begin{array}{l}\text { The mutants lost in vitro inhibitory activity against } S \text {. scabiei in antibiotic and } \\
\text { co-plate assay, while retaining the biocontrol ability in soil }\end{array}$ & {$[167]$} \\
\hline B. amyloliquefaciens subsp. plantarum FZB42 & $\begin{array}{c}\text { Production of cyclic lipopeptides and volatiles }=>\text { pathways of induced } \\
\text { systemic resistance }\end{array}$ & [168] \\
\hline $\begin{array}{l}\text { Agrobacterium tumefaciens C58 attM gene } \\
\text { introduced to S. scabiei }\end{array}$ & $\begin{array}{c}\text { No disease symptoms in planta, altered morphological } \\
\text { differentiation-quorum quenching paralyzing } \gamma \text {-butyrolactone signaling } \\
\text { pathway }\end{array}$ & {$[161]$} \\
\hline
\end{tabular}

The variation in the microbial community response might be connected to the mechanisms of suppression provided by the inoculated strains. Mostly, production of antibiotics against the pathogens is involved, while the identified compounds include geldanamycin [166], phenazine-1-carboxylic acid [163,164], isatropolone C [4], azalomycin [145] or antimicrobial peptides $[154,165]$. However, the strains also produce compounds such as indole-3-acetic acid or siderophores and enable nitrogen fixation and phosphate solubilization [145] or remove signaling through $\gamma$-butyrolactone pathway [161].

In conclusion, the inoculated strains control CS severity not only directly by antibiosis against pathogens but also through nutrition, metabolism and signaling in the plantsoil-microbe interactions. Thus, it seems that inoculation with locally isolated biocontrol strains may be a safer and more effective approach compared to application of globally distributed products, because the local strains might be more adapted to local soil and climate conditions and also to local microbial communities. That might be useful not only for lower disturbance but also for easier adaptation of inoculated strains $[31,169]$.

\section{Conclusions}

Soil mineral nutrients are often in an unbalanced state due to fertilization and intensive soil exploitation by agriculture practices [64]. That negatively affects plant growth, productivity and health as well as soil quality and biodiversity. This review suggests that balanced nutrition together with promotion of suppressive microbial communities represent key components in the management of potato common scab. Two approaches can be used to improve the current state of soil, which leads to improved CS suppression. Firstly, supplying soils with the limiting nutrient and/or microbial strain(s) that solubilize the missing nutrients, and secondly, supporting microbial communities that are competitive or antagonistic to the pathogen by addition of peat or a long-decomposed and largely recalcitrant organic matter. In contrast, additions of organic matter or fertilizers containing high amounts of nitrogen should be carefully evaluated, because nitrogen recycling seems to influence CS severity in both directions. To further support CS suppression, it is necessary to carefully select potato cultivars according to their different micronutrient requirements 
and accumulation $[44,71]$. Furthermore, it is important to consider that individual cultivars have various interactions with rhizosphere microorganisms, and those may enhance but also diminish the plant-microbe interactions $[28,33,135]$. Inoculated biocontrol strains affect not only the pathogen but also the potato plants, the autochthonous microbial community and the soil chemistry, so their impact on the local microbial community also needs to be evaluated prior to their application. Soil chemical status and organic matter should be regularly assessed in more detail to determine the missing elements and the quality of humus.

Focusing on future research, more attention should be paid to plant-microbe-soil interactions occurring in the nearest compartments surrounding potato tubers. These may include the transfer of microorganisms between soil and plant microbiomes, decomposition pathways which lead to compounds influencing the pathogenicity of streptomycetes or metagenomic and metabolomic studies aiming to determine the processes involved in the development of soil suppressiveness. Although long-term monoculture was suggested as the best strategy to achieve long-lasting suppression by streptomycetes [31], new knowledge about the general suppression of CS may bring novel inspiration for management of the disease.

Author Contributions: Original draft preparation, J.K., D.R., E.S. and M.S.-M.; review and editing, M.S.-M., A.S. and T.P. All authors have read and agreed to the published version of the manuscript.

Funding: This work was supported by the Ministry of Agriculture of the Czech Republic, project QK1810370.

Acknowledgments: We would like to thank A. Ghosh and K. Strozewski for English editing.

Conflicts of Interest: The authors declare no conflict of interest.

\section{References}

1. Mendes, R.; Garbeva, P.; Raaijmakers, J.M. The rhizosphere microbiome: Significance of plant beneficial, plant pathogenic, and human pathogenic microorganisms. FEMS Microbiol. Rev. 2013, 37, 634-663. [CrossRef] [PubMed]

2. Vitousek, P.M.; Porder, S.; Houlton, B.Z.; Chadwick, O.A. Terrestrial phosphorus limitation: Mechanisms, implications, and nitrogen-phosphorus interactions. Ecol. Appl. 2010, 20, 5-15. [CrossRef] [PubMed]

3. Brühl, C.A.; Zaller, J.G. Biodiversity decline as a consequence of an inappropriate environmental risk assessment of pesticides. Front. Environ. Sci. 2019, 7, 177. [CrossRef]

4. Sarwar, A.; Latif, Z.; Zhang, S.; Zhu, J.; Zechel, D.L.; Bechthold, A. Biological control of potato common scab with rare isatropolone C compound produced by plant growth promoting Streptomyces A1RT. Front. Microbiol. 2018, 9, 1126. [CrossRef] [PubMed]

5. Dordas, C. Role of nutrients in controlling plant diseases in sustainable agriculture. A review. Agron. Sustain. Dev. 2008, 28, 33-46. [CrossRef]

6. Hooda, P.S. Trace Elements in Soils; John Wiley \& Sons Ltd.: Chichester, UK, 2010.

7. Aznar, A.; Chen, N.W.G.; Thomine, S.; Dellagi, A. Immunity to plant pathogens and iron homeostasis. Plant Sci. 2015, $240,90-97$. [CrossRef]

8. Pascale, A.; Proietti, S.; Pantelides, I.S.; Stringlis, I.A. Modulation of the root microbiome by plant molecules: The basis for targeted disease suppression and plant growth promotion. Front. Plant Sci. 2020, 10, 1-23. [CrossRef] [PubMed]

9. Compant, S.; Clément, C.; Sessitsch, A. Plant growth-promoting bacteria in the rhizo- and endosphere of plants: Their role, colonization, mechanisms involved and prospects for utilization. Soil Biol. Biochem. 2010, 42, 669-678. [CrossRef]

10. Huber, D.M.; Jones, J.B. The role of magnesium in plant disease. Plant Soil 2013, 368, 73-85. [CrossRef]

11. Rosen, C.J.; Kelling, K.A.; Stark, J.C.; Porter, G.A. Optimizing phosphorus fertilizer management in potato production. Am. J. Potato Res. 2014, 91, 145-160. [CrossRef]

12. Spann, T.M.; Schumann, A.W. Mineral Nutrition Contributes to Plant Disease and Pest Resistance; HS1181, One of a Series of the Horticultural Sciences Department; University of Florida/IFAS Extension: Gainesville, FL, USA, 2013.

13. Abujabhah, I.S.; Bound, S.A.; Doyle, R.; Bowman, J.P. Effects of biochar and compost amendments on soil physico-chemical properties and the total community within a temperate agricultural soil. Appl. Soil Ecol. 2016, 98, 243-253. [CrossRef]

14. Gao, Z.; Karlsson, I.; Geisen, S.; Kowalchuk, G.; Jousset, A. Protists: Puppet masters of the rhizosphere microbiome. Trends Plant Sci. 2019, 24, 165-176. [CrossRef]

15. Lambert, D.H.; Powelson, M.L.; Stevenson, W.R. Nutritional interactions influencing diseases of potato. Am. J. Potato Res. 2005, 82, 309-319. [CrossRef] 
16. Lazarovits, G.; Hill, J.; Patterson, G.; Conn, K.L.; Crump, N.S. Edaphic soil levels of mineral nutrients, pH, organic matter, and cationic exchange capacity in the geocaulosphere associated with potato common scab. Phytopathology 2007, 97, 1071-1082. [CrossRef] [PubMed]

17. Davis, J.R.; McDole, R.E.; Callihan, R.H. Fertilizer effects on common scab of potato and the relation of calcium and phosphatephosphorus. Phytopathology 1976, 66, 1236-1241. [CrossRef]

18. Soltani, N.; Conn, K.L.; Abbasi, P.A.; Lazarovits, G. Reduction of potato scab and verticillium wilt with ammonium lignosulfonate soil amendment in four Ontario potato fields. Can. J. Plant Pathol. 2002, 24, 332-339. [CrossRef]

19. Lazarovits, G. Managing soilborne disease of potatoes using ecologically based approaches. Am. J. Potato Res. 2010, 87, 401-411. [CrossRef]

20. Bailey, K.L.; Lazarovits, G. Suppressing soil-borne diseases with residue management and organic amendments. Soil Tillage Res. 2003, 72, 169-180. [CrossRef]

21. Abbasi, P.A.; Conn, K.L.; Lazarovits, G. Effect of fish emulsion used as a preplanting soil amendment on verticillium wilt, scab, and tuber yield of potato. Can. J. Plant Pathol. 2006, 28, 509-518. [CrossRef]

22. Kyselková, M.; Moënne-Loccoz, Y. Pseudomonas and other microbes in disease-suppressive soils. In Organic Fertilisation, Soil Quality and Human Health, Sustainable Agriculture Reviews 9; Lichtfouse, E., Ed.; Springer Science+Business Media B.V.: Dordrecht, The Netherlands, 2012; Volume 9, pp. 93-140. [CrossRef]

23. Shi, W.; Li, M.; Wei, G.; Tian, R.; Li, C.; Wang, B.; Lin, R.; Shi, C.; Chi, X.; Zhou, B.; et al. The occurrence of potato common scab correlates with the community composition and function of the geocaulosphere soil microbiome. Microbiome 2019, 7, 1-18. [CrossRef]

24. Andreote, F.D.; Rocha, U.N.D.; Araújo, W.L.; Azevedo, J.L.; Van Overbeek, L.S. Effect of bacterial inoculation, plant genotype and developmental stage on root-associated and endophytic bacterial communities in potato (Solanum tuberosum). Antonie van Leeuwenhoek 2010, 97, 389-399. [CrossRef]

25. Manter, D.K.; Delgado, J.A.; Holm, D.G.; Stong, R.A. Pyrosequencing reveals a highly diverse and cultivar-specific bacterial endophyte community in potato roots. Microb. Ecol. 2010, 60, 157-166. [CrossRef] [PubMed]

26. Braun, S.; Gevens, A.; Charkowski, A.; Allen, C.; Jansky, S. Potato common scab: A review of the causal pathogens, management practices, varietal resistance screening methods, and host resistance. Am. J. Potato Res. 2017, 94, 283-296. [CrossRef]

27. Sagova-Mareckova, M.; Daniel, O.; Omelka, M.; Kristufek, V.; Divis, J.; Kopecky, J. Determination of factors associated with natural soil suppressivity to potato common scab. PLoS ONE 2015, 10, e0116291. [CrossRef] [PubMed]

28. Kopecky, J.; Samkova, Z.; Sarikhani, E.; Kyselková, M.; Omelka, M.; Kristufek, V.; Divis, J.; Grundmann, G.G.; Moënne-Loccoz, Y.; Sagova-Mareckova, M. Bacterial, archaeal and micro-eukaryotic communities characterize a disease-suppressive or conducive soil and a cultivar resistant or susceptible to common scab. Sci. Rep. 2019, 9, 1-14. [CrossRef] [PubMed]

29. Neeno-Eckwall, E.C.; Kinkel, L.L.; Schottel, J.L. Competition and antibiosis in the biological control of potato scab. Can. J. Microbiol. 2001, 47, 332-340. [CrossRef] [PubMed]

30. Kobayashi, A.; Kobayashi, Y.O.; Someya, N.; Ikeda, S. Community analysis of root-and tuber-associated bacteria in field-grown potato plants harboring different resistance levels against common scab. Microbes Environ. 2015, 30, 301-309. [CrossRef] [PubMed]

31. Schlatter, D.; Kinkel, L.; Thomashow, L.; Weller, D.; Paulitz, T. Disease suppressive soils: New insights from the soil microbiome. Phytopathology 2017, 107, 1284-1297. [CrossRef]

32. Sagova-Mareckova, M.; Omelka, M.; Kopecky, J. Sequential analysis of soil factors related to common scab of potatoes. FEMS Microbiol. Ecol. 2017, 93, fiw201. [CrossRef] [PubMed]

33. Sarikhani, E.; Sagova-Mareckova, M.; Omelka, M.; Kopecky, J. The effect of peat and iron supplements on the severity of potato common scab and bacterial community in tuberosphere soil. FEMS Microbiol. Ecol. 2017, 93, fiw206. [CrossRef] [PubMed]

34. Hopkins, B.G.; Horneck, D.A.; MacGuidwin, A.E. Improving phosphorus use efficiency through potato rhizosphere modification and extension. Am. J. Potato Res. 2014, 91, 161-174. [CrossRef]

35. Lambert, D.H.; Manzer, F.E. Relationship of calcium to potato scab. Phytopathology 1991, 81, 632-636. [CrossRef]

36. Krištůfek, V.; Diviš, J.; Dostálková, I.; Kalčík, J. Accumulation of mineral elements in tuber periderm of potato cultivars differing in susceptibility to common scab. Potato Res. 2000, 43, 107-114. [CrossRef]

37. Lacey, M.J.; Wilson, C.R. Relationship of common scab incidence of potatoes grown in Tasmanian ferrosol soils with pH, exchangeable cations and other chemical properties of those soils. J. Phytopathol. 2001, 149, 679-683. [CrossRef]

38. Schroeder, R.A.; Albrecht, W.A. Plant nutrition and the hydrogen ion: II. Potato scab. Soil Sci. 1942, 53, 481-488. [CrossRef]

39. Wiechel, T.J.; Crump, N.S.; Gilkes, R.J. Soil nutrition and common scab disease of potato in Australia. In Proceedings of the 19th World Congress of Soil Science, Soil Solutions for a Changing World, Brisbane, Australia, 1-6 August 2010; pp. 1-6.

40. Koch, M.; Naumann, M.; Pawelzik, E.; Gransee, A.; Thiel, H. The importance of nutrient management for potato production Part I: Plant nutrition and yield. Potato Res. 2020, 63, 97-119. [CrossRef]

41. Krauss, A. Balanced nutrition and biotic stress. In Proceedings of the IFA Agricultural Conference on Managing Plant Nutrition, Barcelona, Spain, 29 June-2 July 1999.

42. Loria, R.; Kers, J.; Joshi, M. Evolution of plant pathogenicity in Streptomyces. Annu. Rev. Phytopathol. 2006, 44, 469-487. [CrossRef]

43. Busse, J.S.; Palta, J.P. Investigating the in vivo calcium transport path to developing potato tuber using ${ }^{45} \mathrm{Ca}$ : A new concept in potato tuber calcium nutrition. Physiol. Plant. 2006, 128, 313-323. [CrossRef] 
44. Krištůfek, V.; Diviš, J.; Omelka, M.; Kopecký, J.; Sagová-Marečková, M. Site, year and cultivar effects on relationships between periderm nutrient contents and common scab severity. Am. J. Potato Res. 2015, 92, 473-482. [CrossRef]

45. Loria, R.; Bukhalid, R.A.; Fry, B.A.; King, R.R. Plant pathogenicity in the genus Streptomyces. Plant Dis. 1997, 81, 836-846. [CrossRef]

46. Klikocka, $\mathrm{H}$. Influence of NPK fertilization enriched with $\mathrm{S}, \mathrm{Mg}$, and micronutrients contained in liquid fertilizer Insol 7 on potato tubers yield (Solanum tuberosum L.) and infestation of tubers with Streptomyces scabies and Rhizoctonia solani. J. Elem. 2009, 14, 271-288. [CrossRef]

47. Davis, J.R.; Garner, J.G.; Callihan, R.H. Effects of gypsum, sulfur, terraclor and terraclor super-x for potato scab control. Am. Potato J. 1974, 51, 35-43. [CrossRef]

48. Klikocka, H.; Haneklaus, S.; Bloem, E.; Schnug, E. Influence of sulfur fertilization on infection of potato tubers with Rhizoctonia solani and Streptomyces scabies. J. Plant Nutr. 2005, 28, 819-833. [CrossRef]

49. Kertesz, M.A.; Mirleau, P. The role of soil microbes in plant sulphur nutrition. J. Exp. Bot. 2004, 55, 1939-1945. [CrossRef] [PubMed]

50. Inceoğlu, Ö.; Salles, J.F.; van Elsas, J.D. Soil and cultivar type shape the bacterial community in the potato rhizosphere. Microb. Ecol. 2012, 63, 460-470. [CrossRef]

51. Bloem, E.; Haneklaus, S.; Schnug, E. Milestones in plant sulfur research on sulfur-induced-resistance (SIR) in Europe. Front. Plant Sci. 2015, 5, 779. [CrossRef] [PubMed]

52. Klikocka, H.; Kobialka, A.; Juszczak, D.; Glowacka, A. The influence of sulphur on phosphorus and potassium content in potato tubers (Solanum tuberosum L.). J. Elem. 2015, 20, 621-629. [CrossRef]

53. Senbayram, M.; Gransee, A.; Wahle, V.; Thiel, H. Role of magnesium fertilisers in agriculture: Plant-soil continuum. Crop. Pasture Sci. 2015, 66, 1219-1229. [CrossRef]

54. Gransee, A.; Führs, H. Magnesium mobility in soils as a challenge for soil and plant analysis, magnesium fertilization and root uptake under adverse growth conditions. Plant Soil 2013, 368, 5-21. [CrossRef]

55. Marschner, P. Marschner's Mineral. Nutrition of Higher Plants, 3rd ed.; Marschner, P., Ed.; Elsevier Inc.: Amsterdam, The Netherlands, 2012. [CrossRef]

56. Shaul, O. Magnesium transport and function in plants: The tip of the iceberg. BioMetals 2002, 15, 309-323. [CrossRef] [PubMed]

57. Huber, D.M.; Wilhelm, N.S. The role of manganese in resistance to plant diseases. In Manganese in Soils and Plants. Developments in Plant and Soil Sciences; Graham, R.D., Hannam, R.J., Uren, N.C., Eds.; Springer: Dordrecht, The Netherlands, 1988; Volume 33, pp. 155-173. [CrossRef]

58. McGregor, A.J.; Wilson, G.C.S. The influence of manganese on the development of potato scab. Plant Soil 1966, 25, 3-16. [CrossRef]

59. Barnes, E.D. The effects of irrigation, manganese sulphate and sulphur applications on common scab of the potato. Rec. Agric. Res. 1972, 20, 35-44.

60. Orlov, D.S. Soil Chemistry; A.A. Balkema Publishers: Rotterdam, The Netherlands, 1992.

61. Mukhopadhyay, M.J.; Sharma, A. Manganese in cell metabolism of higher plants. Bot. Rev. 1991, 57, 117-149. [CrossRef]

62. Westermann, D.T. Nutritional requirements of potatoes. Am. J. Potato Res. 2005, 82, 301-307. [CrossRef]

63. Broadley, M.; Brown, P.; Cakmak, I.; Rengel, Z.; Zhao, F. Function of nutrients: Micronutrients. In Marschner's Mineral Nutrition of Higher Plants: Third Edition; Marschner, P., Ed.; Elsevier Inc.: Amsterdam, The Netherlands, 2012; pp. 191-248. [CrossRef]

64. Huber, D.M.; Haneklaus, S. Managing nutrition to control plant disease. Landbauforsch. Volkenrode 2007, 57, 313-322.

65. Rogers, P.F. Organic manuring for potato scab control and its relation to soil manganese. Ann. Appl. Biol. 1969, 63, 371-378. [CrossRef]

66. Roy, R.N.; Finck, A.; Blair, G.J.; Tandon, H.L.S. Plant Nutrition for Food Security: A Guide for Integrated Nutrient Management; FAO: Rome, Italy, 2006; Volume 16.

67. Rout, G.R.; Sahoo, S. Role of iron in plant growth and metabolism. Rev. Agric. Sci. 2015, 3, 1-24. [CrossRef]

68. Glick, B.R. Plant growth-promoting bacteria: Mechanisms and applications. Scientifica 2012, 2012, 1-15. [CrossRef] [PubMed]

69. Colombo, C.; Palumbo, G.; He, J.-Z.; Pinton, R.; Cesco, S. Review on iron availability in soil: Interaction of Fe minerals, plants, and microbes. J. Soils Sediments 2014, 14, 538-548. [CrossRef]

70. Adamski, J.M.; Peters, J.A.; Danieloski, R.; Bacarin, M.A. Excess iron-induced changes in the photosynthetic characteristics of sweet potato. J. Plant Physiol. 2011, 168, 2056-2062. [CrossRef]

71. Öztürk, E.; Atsan, E.; Polat, T.; Kara, K. Variation in heavy metal concentrations of potato (Solanum tuberosum L.) cultivars. J. Anim. Plant Sci. 2011, 21, 235-239.

72. Kramer, J.; Özkaya, Ö.; Kümmerli, R. Bacterial siderophores in community and host interactions. Nat. Rev. Microbiol. 2020, 18, 152-163. [CrossRef] [PubMed]

73. Seipke, R.F.; Song, L.; Bicz, J.; Laskaris, P.; Yaxley, A.M.; Challis, G.L.; Loria, R. The plant pathogen Streptomyces scabies 87-22 has a functional pyochelin biosynthetic pathway that is regulated by TetR- and AfsR-family proteins. Microbiology 2011, 157, $2681-2693$. [CrossRef] [PubMed]

74. Kodani, S.; Bicz, J.; Song, L.; Deeth, R.J.; Ohnishi-Kameyama, M.; Yoshida, M.; Ochi, K.; Challis, G.L. Structure and biosynthesis of scabichelin, a novel tris-hydroxamate siderophore produced by the plant pathogen Streptomyces scabies 87.22. Org. Biomol. Chem. 2013, 11, 4686-4694. [CrossRef] [PubMed] 
75. Graham, R.D.; Webb, M.J. Micronutrients and disease resistance and tolerance in plants. In Micronutrients in Agriculture; Mortvedt, J.J., Ed.; John Wiley \& Sons, Ltd.: Hoboken, NJ, USA, 1991; pp. 329-370. [CrossRef]

76. Banerjee, S.; Kirkby, C.A.; Schmutter, D.; Bissett, A.; Kirkegaard, J.A.; Richardson, A.E. Network analysis reveals functional redundancy and keystone taxa amongst bacterial and fungal communities during organic matter decomposition in an arable soil. Soil Biol. Biochem. 2016, 97, 188-198. [CrossRef]

77. van der Wal, A.; de Boer, W. Dinner in the dark: Illuminating drivers of soil organic matter decomposition. Soil Biol. Biochem. 2017, 105, 45-48. [CrossRef]

78. Masson-Boivin, C.; Sachs, J.L. Symbiotic nitrogen fixation by rhizobia-The roots of a success story. Curr. Opin. Plant Biol. 2018, 44, 7-15. [CrossRef]

79. Gaby, J.C.; Buckley, D.H. A global census of nitrogenase diversity. Environ. Microbiol. 2011, 13, 1790-1799. [CrossRef]

80. Clark, D.R.; McKew, B.A.; Dong, L.F.; Leung, G.; Dumbrell, A.J.; Stott, A.; Grant, H.; Nedwell, D.B.; Trimmer, M.; Whitby, C. Mineralization and nitrification: Archaea dominate ammonia-oxidising communities in grassland soils. Soil Biol. Biochem. 2020, 143, 107725. [CrossRef]

81. Holloway, J.M.; Dahlgren, R.A. Nitrogen in rock: Occurrences and biogeochemical implications. Glob. Biogeochem. Cycles 2002, 16. [CrossRef]

82. Lazarovits, G.; Conn, K.L.; Potter, J. Reduction of potato scab, verticillium wilt, and nematodes by soymeal and meat and bone meal in two Ontario potato fields. Can. J. Plant Pathol. 1999, 21, 345-353. [CrossRef]

83. Conn, K.L.; Lazarovits, G. Impact of animal manures on verticillium wilt, potato scab, and soil microbial populations. Can. J. Plant Pathol. 1999, 21, 81-92. [CrossRef]

84. Ospina, C.A.; Lammerts van Bueren, E.T.; Allefs, J.J.H.M.; Engel, B.; van der Putten, P.E.L.; van der Linden, C.G.; Struik, P.C. Diversity of crop development traits and nitrogen use efficiency among potato cultivars grown under contrasting nitrogen regimes. Euphytica 2014, 199, 13-29. [CrossRef]

85. Richardson, A.E.; Simpson, R.J. Soil microorganisms mediating phosphorus availability. Plant Physiol. 2011, 156, 989-996. [CrossRef] [PubMed]

86. Jalali, M. Phosphorus availability as influenced by organic residues in five calcareous soils. Compost Sci. Util. 2009, 17, 241-246. [CrossRef]

87. Hammond, J.P.; Broadley, M.R.; White, P.J. Genetic responses to phosphorus deficiency. Ann. Bot. 2004, 94, 323-332. [CrossRef]

88. Johnson, J.F.; Vance, C.P.; Allan, D.L. Phosphorus deficiency in Lupinus albus (altered lateral root development and enhanced expression of phosphoenolpyruvate carboxylase). Plant Physiol. 1996, 112, 31-41. [CrossRef]

89. Sattar, A.; Naveed, M.; Ali, M.; Zahir, Z.A.; Nadeem, S.M.; Yaseen, M.; Meena, V.S.; Farooq, M.; Singh, R.; Rahman, M.; et al. Perspectives of potassium solubilizing microbes in sustainable food production system: A review. Appl. Soil Ecol. 2019, 133, 146-159. [CrossRef]

90. Xiao, Y.; Wang, X.; Chen, W.; Huang, Q. Isolation and identification of three potassium-solubilizing bacteria from rape rhizospheric soil and their effects on ryegrass. Geomicrobiol. J. 2017, 34, 873-880. [CrossRef]

91. Bonanomi, G.; Antignani, V.; Capodilupo, M.; Scala, F. Identifying the characteristics of organic soil amendments that suppress soilborne plant diseases. Soil Biol. Biochem. 2010, 42, 136-144. [CrossRef]

92. Bernard, E.; Larkin, R.P.; Tavantzis, S.; Erich, M.S.; Alyokhin, A.; Gross, S.D. Rapeseed rotation, compost and biocontrol amendments reduce soilborne diseases and increase tuber yield in organic and conventional potato production systems. Plant Soil 2014, 374, 611-627. [CrossRef]

93. Larkin, R.P.; Honeycutt, C.W.; Griffin, T.S.; Olanya, O.M.; Halloran, J.M.; He, Z. Effects of different potato cropping system approaches and water management on soilborne diseases and soil microbial communities. Phytopathology 2011, 101, 58-67. [CrossRef]

94. Mazzola, M. Mechanisms of natural soil suppressiveness to soilborne diseases. Antonie van Leeuwenhoek 2002, $81,557-564$. [CrossRef] [PubMed]

95. Al-Mughrabi, K.I.; Bertheleme, C.; Livingston, T.; Burgoyne, A.; Poirier, R.; Vikram, A. Aerobic compost tea, compost and a combination of both reduce the severity of common scab (Streptomyces scabiei) on potato tubers. J. Plant Sci. 2008, 3, 168-175. [CrossRef]

96. Larkin, R.P.; Griffin, T.S. Control of soilborne potato diseases using Brassica green manures. Crop. Prot. 2007, 26, 1067-1077. [CrossRef]

97. Wilson, C.; Zebarth, B.J.; Goyer, C.; Burton, D.L. Effect of diverse compost products on soilborne diseases of potato. Compost Sci. Util. 2018, 26, 156-164. [CrossRef]

98. Ninh, H.T.; Grandy, A.S.; Wickings, K.; Snapp, S.S.; Kirk, W.; Hao, J. Organic amendment effects on potato productivity and quality are related to soil microbial activity. Plant Soil 2014, 386, 223-236. [CrossRef]

99. Curless, M.A.; Kelling, K.A.; Speth, P.E.; Stevenson, W.R.; James, R.V. Effect of manure application timing on potato yield, quality, and disease incidence. Am. J. Potato Res. 2012, 89, 363-373. [CrossRef]

100. Alabouvette, C.; Hoeper, H.; Lemanceau, P. Soil suppressiveness to diseases induced by soilborne plant pathogens. In Soil Biochemistry; Stotzky, G., Bollag, J.-M., Eds.; Marcel Dekker Inc.: New York, NY, USA, 1996; Volume 9, pp. 371-413.

101. Brevik, E.C.; Cerdà, A.; Mataix-Solera, J.; Pereg, L.; Quinton, J.N.; Six, J.; Van Oost, K. The interdisciplinary nature of soil. Soil 2015, 1, 117-129. [CrossRef] 
102. Hao, J.J.; Liu, H.; Donis-Gonzalez, I.R.; Lu, X.H.; Jones, D.; Fulbright, D.W. Antimicrobial activity of chestnut extracts for potential use in managing soilborne plant pathogens. Plant Dis. 2012, 96, 354-360. [CrossRef]

103. Millard, W.A. Common scab of potatoes. Ann. Appl. Biol. 1923, 10, 70-88. [CrossRef]

104. Larkin, R.P.; Lynch, R.P. Use and effects of different brassica and other rotation crops on soilborne diseases and yield of potato. Horticulturae 2018, 4, 37. [CrossRef]

105. Sakuma, F.; Maeda, M.; Takahashi, M.; Hashizume, K.; Kondo, N. Suppression of common scab of potato caused by Streptomyces turgidiscabies using lopsided oat green manure. Plant Dis. 2011, 95, 1124-1130. [CrossRef]

106. Tomihama, T.; Nishi, Y.; Mori, K.; Shirao, T.; Iida, T.; Uzuhashi, S.; Ohkuma, M.; Ikeda, S. Rice bran amendment suppresses potato common scab by increasing antagonistic bacterial community levels in the rhizosphere. Phytopathology 2016, 106, 719-728. [CrossRef]

107. Mishra, K.K.; Srivastava, J.S. Soil amendments to control common scab of potato. Potato Res. 2004, 47, 101-109. [CrossRef]

108. Abdel-Hamid, M.A.M.; Hassan, E.A.; Elbana, E.A.; Galal, A.A. Management of potato common scab caused by Streptomyces scabies using compost and compost tea. Minia J. Agric. Res. Dev. 2016, 36, 293-305.

109. Roy, J.; Lafontaine, P.; Chabot, R.; Beaulieu, C. Dehydrated pork manure by-product: Effect of a chitosan amendment on bacterial community and common scab incidence. Phytoprotection 2009, 90, 107-115. [CrossRef]

110. Larkin, R.P.; Honeycutt, C.W.; Griffin, T.S.; Olanya, O.M.; He, Z.; Halloran, J.M. Cumulative and residual effects of different potato cropping system management strategies on soilborne diseases and soil microbial communities over time. Plant Pathol. 2017, 66, 437-449. [CrossRef]

111. Sun, P.; Otto-Hanson, L.K.; Arenz, B.E.; Ma, Q.; Kinkel, L.L. Molecular and functional characteristics of streptomycete communities in relation to soil factors and potato common scab. Eur. J. Soil Biol. 2015, 70, 58-66. [CrossRef]

112. Schlatter, D.; Fubuh, A.; Xiao, K.; Hernandez, D.; Hobbie, S.; Kinkel, L. Resource amendments influence density and competitive phenotypes of Streptomyces in soil. Microb. Ecol. 2009, 57, 413-420. [CrossRef] [PubMed]

113. Wiggins, B.E.; Kinkel, L.L. Green manures and crop sequences influence potato diseases and pathogen inhibitory activity of indigenous streptomycetes. Phytopathology 2005, 95, 178-185. [CrossRef] [PubMed]

114. Kinkel, L.L.; Schlatter, D.C.; Bakker, M.G.; Arenz, B.E. Streptomyces competition and co-evolution in relation to plant disease suppression. Res. Microbiol. 2012, 163, 490-499. [CrossRef]

115. Fernández-Romero, M.L.; Clark, J.M.; Collins, C.D.; Parras-Alcántara, L.; Lozano-García, B. Evaluation of optical techniques for characterising soil organic matter quality in agricultural soils. Soil Tillage Res. 2016, 155, 450-460. [CrossRef]

116. Dippenaar, B.J. Environmental and Control Studies of the Common Scab Disease of Potatoes Caused by Actinomyces Scabies (Thaxt.) Guss. Master's Thesis, Stellenbosch University, Stellenbosch, South Africa, 1933.

117. Wach, M.J.; Krasnoff, S.B.; Loria, R.; Gibson, D.M. Effect of carbohydrates on the production of thaxtomin A by Streptomyces acidiscabies. Arch. Microbiol. 2007, 188, 81-88. [CrossRef]

118. Jourdan, S.; Francis, I.M.; Kim, M.J.; Salazar, J.J.C.; Planckaert, S.; Frère, J.M.; Matagne, A.; Kerff, F.; Devreese, B.; Loria, R.; et al. The CebE/MsiK transporter is a doorway to the cello-oligosaccharide-mediated induction of Streptomyces scabies pathogenicity. Sci. Rep. 2016, 6, 27144. [CrossRef] [PubMed]

119. Deflandre, B.; Thiébaut, N.; Planckaert, S.; Jourdan, S.; Anderssen, S.; Hanikenne, M.; Devreese, B.; Francis, I.; Rigali, S. Deletion of $\mathrm{bglC}$ triggers a genetic compensation response by awakening the expression of alternative beta-glucosidase. Biochim. Biophys. Acta Gene Regul. Mech. 2020, 1863, 194615. [CrossRef] [PubMed]

120. Fierer, N. Embracing the unknown: Disentangling the complexities of the soil microbiome. Nat. Rev. Microbiol. 2017, 15, 579-590. [CrossRef] [PubMed]

121. Rolfe, S.A.; Griffiths, J.; Ton, J. Crying out for help with root exudates: Adaptive mechanisms by which stressed plants assemble health-promoting soil microbiomes. Curr. Opin. Microbiol. 2019, 49, 73-82. [CrossRef]

122. Sasse, J.; Martinoia, E.; Northen, T. Feed your friends: Do plant exudates shape the root microbiome? Trends Plant Sci. 2018, 23, 25-41. [CrossRef]

123. Geddes, B.A.; Paramasivan, P.; Joffrin, A.; Thompson, A.L.; Christensen, K.; Jorrin, B.; Brett, P.; Conway, S.J.; Oldroyd, G.E.D.; Poole, P.S. Engineering transkingdom signalling in plants to control gene expression in rhizosphere bacteria. Nat. Commun. 2019, 10, 1-11. [CrossRef] [PubMed]

124. Guyonnet, J.P.; Guillemet, M.; Dubost, A.; Simon, L.; Ortet, P.; Barakat, M.; Heulin, T.; Achouak, W.; Haichar, F.E.Z. Plant nutrient resource use strategies shape active rhizosphere microbiota through root exudation. Front. Plant Sci. 2018, 9, 1662. [CrossRef] [PubMed]

125. Korenblum, E.; Dong, Y.; Szymanski, J.; Panda, S.; Jozwiak, A.; Massalha, H.; Meir, S.; Rogachev, I.; Aharoni, A. Rhizosphere microbiome mediates systemic root metabolite exudation by root-to-root signaling. Proc. Natl. Acad. Sci. USA 2020, 117, 3874-3883. [CrossRef]

126. Huber, D.; Römheld, V.; Weinmann, M. Relationship between nutrition, plant diseases and pests. In Marschner's Mineral Nutrition of Higher Plants, 3rd ed.; Marschner, P., Ed.; Elsevier Inc.: Amsterdam, The Netherlands, 2012; pp. 283-298. [CrossRef]

127. Gu, Y.; Wei, Z.; Wang, X.; Friman, V.-P.; Huang, J.; Wang, X.; Mei, X.; Xu, Y.; Shen, Q.; Jousset, A. Pathogen invasion indirectly changes the composition of soil microbiome via shifts in root exudation profile. Biol. Fertil. Soils 2016, 52, 997-1005. [CrossRef]

128. Lorang, J.M.; Liu, D.; Anderson, N.A.; Schottel, J.L. Identification of potato scab inducing and suppressive species of Streptomyces. Phytopathology 1995, 85, 261-268. [CrossRef] 
129. Meng, Q.X.; Jiang, H.H.; Hanson, L.E.; Hao, J.J. Characterizing a novel strain of Bacillus amyloliquefaciens BAC03 for potential biological control application. J. Appl. Microbiol. 2012, 113, 1165-1175. [CrossRef] [PubMed]

130. Rosenzweig, N.; Tiedje, J.M.; Quensen, J.F.; Meng, Q.; Hao, J.J. Microbial communities associated with potato common scabsuppressive soil determined by pyrosequencing analyses. Plant Dis. 2012, 96, 718-725. [CrossRef]

131. Almario, J.; Kyselková, M.; Kopecký, J.; Ságová-Marečková, M.; Muller, D.; Grundmann, G.L.; Moënne-Loccoz, Y. Assessment of the relationship between geologic origin of soil, rhizobacterial community composition and soil receptivity to tobacco black root rot in Savoie region (France). Plant Soil 2013, 371, 397-408. [CrossRef]

132. Tegg, R.S.; Gill, W.M.; Thompson, H.K.; Davies, N.W.; Ross, J.J.; Wilson, C.R. Auxin-induced resistance to common scab disease of potato linked to inhibition of thaxtomin A toxicity. Plant Dis. 2008, 92, 1321-1328. [CrossRef] [PubMed]

133. Fiore-Donno, A.M.; Weinert, J.; Wubet, T.; Bonkowski, M. Metacommunity analysis of amoeboid protists in grassland soils. Sci. Rep. 2016, 6, 19068. [CrossRef]

134. Jousset, A. Application of protists to improve plant growth in sustainable agriculture. In Rhizotrophs: Plant Growth Promotion to Bioremediation; Mehnaz, S., Ed.; Springer Nature Singapore Pte Ltd.: Singapore, 2017; pp. 263-273. [CrossRef]

135. Weinert, N.; Piceno, Y.; Ding, G.C.; Meincke, R.; Heuer, H.; Berg, G.; Schloter, M.; Andersen, G.; Smalla, K. PhyloChip hybridization uncovered an enormous bacterial diversity in the rhizosphere of different potato cultivars: Many common and few cultivar-dependent taxa. FEMS Microbiol. Ecol. 2011, 75, 497-506. [CrossRef]

136. Hu, H.W.; Zhang, L.M.; Yuan, C.L.; He, J.Z. Contrasting Euryarchaeota communities between upland and paddy soils exhibited similar pH-impacted biogeographic patterns. Soil Biol. Biochem. 2013, 64, 18-27. [CrossRef]

137. Meng, Q.X.; Yin, J.F.; Rosenzweig, N.; Douches, D.; Hao, J.J. Culture-based assessment of microbial communities in soil suppressive to potato common scab. Plant Dis. 2012, 96, 712-717. [CrossRef] [PubMed]

138. Wanner, L.A. High proportions of nonpathogenic Streptomyces are associated with common scab-resistant potato lines and less severe disease. Can. J. Microbiol. 2007, 53, 1062-1075. [CrossRef] [PubMed]

139. Roquigny, R.; Novinscak, A.; Léger, G.; Marcoux, N.; Joly, D.L.; Filion, M. Deciphering the rhizosphere and geocaulosphere microbiomes of potato following inoculation with the biocontrol agent Pseudomonas fluorescens strain LBUM223. Phytobiomes J. 2018, 2, 92-99. [CrossRef]

140. Ardanov, P.; Ovcharenko, L.; Zaets, I.; Kozyrovska, N.; Pirttilä, A.M. Endophytic bacteria enhancing growth and disease resistance of potato (Solanum tuberosum L.). Biol. Control 2011, 56, 43-49. [CrossRef]

141. Raaijmakers, J.M.; Paulitz, T.C.; Steinberg, C.; Alabouvette, C.; Moënne-Loccoz, Y. The rhizosphere: A playground and battlefield for soilborne pathogens and beneficial microorganisms. Plant Soil 2009, 321, 341-361. [CrossRef]

142. Jobin, G.; Couture, G.; Goyer, C.; Brzezinski, R.; Beaulieu, C. Streptomycete spores entrapped in chitosan beads as a novel biocontrol tool against common scab of potato. Appl. Microbiol. Biotechnol. 2005, 68, 104-110. [CrossRef] [PubMed]

143. Kobayashi, Y.O.; Kobayashi, A.; Maeda, M.; Takenaka, S. Isolation of antagonistic Streptomyces sp. against a potato scab pathogen from a field cultivated with wild oat. J. Gen. Plant Pathol. 2012, 78, 62-72. [CrossRef]

144. Lee, H.B.; Cho, J.W.; Park, D.J.; Li, C.T.; Ko, Y.H.; Song, J.H.; Koh, J.S.; Kim, B.J.; Kim, C.J. In vivo screening for biocontrol agents (BCAs) against Streptomyces scabiei causing potato common scab. Plant Pathol. J. 2004, 20, 110-114. [CrossRef]

145. Sarwar, A.; Latif, Z.; Zhang, S.; Hao, J.; Bechthold, A. A potential biocontrol agent Streptomyces violaceusniger AC12AB for managing potato common scab. Front. Microbiol. 2019, 10, 202. [CrossRef]

146. Wang, Z.; Li, Y.; Zhuang, L.; Yu, Y.; Liu, J.; Zhang, L.; Gao, Z.; Wu, Y.; Gao, W.; Ding, G.; et al. A rhizosphere-derived consortium of Bacillus subtilis and Trichoderma harzianum suppresses common scab of potato and increases yield. Comput. Struct. Biotechnol. J. 2019, 17, 645-653. [CrossRef] [PubMed]

147. Schmiedeknecht, G.; Bochow, H.; Junge, H. Use of Bacillus subtilis as biocontrol agent. II. Biological control of potato diseases. J. Plant Dis. Prot. 1998, 105, 376-386.

148. Chen, S.; Zhang, M.; Wang, J.; Lv, D.; Ma, Y.; Zhou, B.; Wang, B. Biocontrol effects of Brevibacillus laterosporus AMCC100017 on potato common scab and its impact on rhizosphere bacterial communities. Biol. Control 2017, 106, 89-98. [CrossRef]

149. Arseneault, T.; Goyer, C.; Filion, M. Pseudomonas fluorescens LBUM223 increases potato yield and reduces common scab symptoms in the field. Phytopathology 2015, 105, 1311-1317. [CrossRef] [PubMed]

150. Singhai, P.K.; Sarma, B.K.; Srivastava, J.S. Biological management of common scab of potato through Pseudomonas species and vermicompost. Biol. Control 2011, 57, 150-157. [CrossRef]

151. Larkin, R.P.; Tavantzis, S. Use of biocontrol organisms and compost amendments for improved control of soilborne diseases and increased potato production. Am. J. Potato Res. 2013, 90, 261-270. [CrossRef]

152. Kobayashi, Y.O.; Kobayashi, A.; Soejima, H.; Takenaka, S. Enhanced suppressive effect of antagonistic Streptomyces sp. WoRs-501 on potato scab in conjunction with other control methods. Jpn. Agric. Res. Q. 2017, 51, 251-257. [CrossRef]

153. Kobayashi, Y.O.; Kobayashi, A.; Maeda, M.; Someya, N.; Takenaka, S. Biological control of potato scab and antibiosis by antagonistic Streptomyces sp. WoRs-501. J. Gen. Plant Pathol. 2015, 81, 439-448. [CrossRef]

154. Han, J.S.; Cheng, J.H.; Yoon, T.M.; Song, J.; Rajkarnikar, A.; Kim, W.G.; Yoo, I.D.; Yang, Y.Y.; Suh, J.W. Biological control agent of common scab disease by antagonistic strain Bacillus sp. sunhua. J. Appl. Microbiol. 2005, 99, 213-221. [CrossRef]

155. Cui, L.; Yang, C.; Wei, L.; Li, T.; Chen, X. Isolation and identification of an endophytic bacteria Bacillus velezensis 8-4 exhibiting biocontrol activity against potato scab. Biol. Control 2020, 141, 104156. [CrossRef] 
156. Nanri, N.; Gohda, Y.; Ohno, M.; Miyabe, K.; Furukawa, K.; Hayashida, S. Growth promotion of fluorescent pseudomonads and control of potato common scab in field soil with non-antibiotic actinomycete-biofertilizer. Biosci. Biotechnol. Biochem. 1992, 56, 1289-1292. [CrossRef]

157. Wanner, L.A.; Kirk, W.W.; Qu, X.S. Field efficacy of nonpathogenic Streptomyces species against potato common scab. J. Appl. Microbiol. 2014, 116, 123-133. [CrossRef] [PubMed]

158. Hiltunen, L.H.; Kelloniemi, J.; Valkonen, J.P.T. Repeated applications of a nonpathogenic Streptomyces strain enhance development of suppressiveness to potato common scab. Plant Dis. 2017, 101, 224-232. [CrossRef]

159. Arseneault, T.; Goyer, C.; Filion, M. Biocontrol of potato common scab is associated with high Pseudomonas fluorescens LBUM223 populations and phenazine-1-carboxylic acid biosynthetic transcript accumulation in the potato geocaulosphere. Phytopathology 2016, 106, 963-970. [CrossRef] [PubMed]

160. Karagoz, K.; Dadasoglu, F.; Mohammadi, P.; Kotan, R. Screening bacterial antagonists to common scab disease. J. Anim. Plant Sci. 2018, 28, 1068-1073.

161. Lin, L.; Xu, X.; Zheng, Y.; Zhang, C. Effects of AttM lactonase on the pathogenicity of Streptomyces scabies. Lett. Appl. Microbiol. 2018, 67, 270-277. [CrossRef] [PubMed]

162. Goyer, C. Isolation and characterization of phages Stsc1 and Stsc3 infecting Streptomyces scabiei and their potential as biocontrol agents. Can. J. Plant Pathol. 2005, 27, 210-216. [CrossRef]

163. St-Onge, R.; Goyer, C.; Filion, M. Pseudomonas spp. can inhibit Streptomyces scabies growth and repress the expression of genes involved in pathogenesis. J. Bacteriol. Parasitol. 2010, 1, 101. [CrossRef]

164. Arseneault, T.; Roquigny, R.; Novinscak, A.; Goyer, C.; Filion, M. Phenazine-1-carboxylic acid-producing Pseudomonas synxantha LBUM223 alters the transcriptome of Streptomyces scabies, the causal agent of potato common scab. Physiol. Mol. Plant Pathol. 2020, 110, 101480. [CrossRef]

165. Liu, Q.; Shen, Y.R.; Yin, K.D. The degradation fragments of gamma-glutamyl transpeptidase from Bacillus subtilis BU108 have antimicrobial activity against Streptomyces scabiei. J. Plant Dis. Prot. 2020. [CrossRef]

166. Agbessi, S.; Beauséjour, J.; Déry, C.; Beaulieu, C. Antagonistic properties of two recombinant strains of Streptomyces melanosporofaciens obtained by intraspecific protoplast fusion. Appl. Microbiol. Biotechnol. 2003, 62, 233-238. [CrossRef] [PubMed]

167. Schottel, J.L.; Shimizu, K.; Kinkel, L.L. Relationships of in vitro pathogen inhibition and soil colonization to potato scab biocontrol by antagonistic Streptomyces spp. Biol. Control 2001, 20, 102-112. [CrossRef]

168. Chowdhury, S.P.; Hartmann, A.; Gao, X.W.; Borriss, R. Biocontrol mechanism by root-associated Bacillus amyloliquefaciens FZB42-A review. Front. Microbiol. 2015, 6, 780. [CrossRef] [PubMed]

169. Sun, P.; Zhao, X.; Shangguan, N.; Chang, D.; Ma, Q. The roles of inoculants' carbon source use in the biocontrol of potato scab disease. Can. J. Microbiol. 2015, 61, 257-262. [CrossRef] [PubMed] 